\title{
Antimalarial Activity of Methanolic Extracts and Solvent Fractions of Combretum molle Leaves in Plasmodium berghei Infected Mice
}

This article was published in the following Dove Press journal: Journal of Experimental Pharmacology

\author{
Melkamu Adigo Shibeshi' \\ Engdaw Fentahun Enyew ${ }^{2}$ \\ Getnet Mequanint Adinew $\mathbb{D D}^{3}$ \\ Tezera Jemere Aragaw ${ }^{3}$
}

'Awi Zone Health Department, Awi Zone, Injibara, Ethiopia; ${ }^{2}$ Department of Human Anatomy, College of Medicine and Health Sciences, University of Gondar, Gondar, Ethiopia; ${ }^{3}$ Department of Pharmacology, College of Medicine and Health Sciences, University of Gondar, Gondar, Ethiopia
Correspondence: Tezera Jemere Aragaw Email tezeraadis1982@gmail.com
Background: Malaria is an infectious disease-causing mortality and morbidity in children and adults. Our study planned to measure the antimalarial activity of Combretum molle extract in vivo assays against Plasmodium berghei in Swiss albino mice.

Methods: Plasmodium berghei was inoculated to healthy mice and methanolic crude extract and solvent fractions of C. molle at 100, 200, and $400 \mathrm{mg} / \mathrm{kg} /$ day were administered. Percent parasitemia inhibition, percent change in weight, temperature, packed cell volume, and mean survival time were determined. Data were analyzed using one-way ANOVA followed by the post hoc Tukey HSD test with SPSS software version 24.0 and $\mathrm{P}<0.05$ considered as statistically significant.

Results: Chemosuppresive effect exerted by the methanolic crude extract ranged between 27 and $68 \%$, chloroform fraction $52.93-67.73 \%$, hexane fraction $23.61-44.97 \%$, and aqueous fraction $29.48-51.13 \%$. The curative effect of the crude extract was within the range of $25-49 \%$, chloroform fraction $42.78-69.22 \%$, and prophylactic effect of the crude extract was within the range of $51-76.2 \% \%$ and chloroform fraction $46.57-71.96 \%$. The utmost effect in all tests on chemosuppresive, curative, prophylactic, prevention of weight loss, temperature and packed cell volume, and an increase in mean survival time was observed at higher doses of the crude extract.

Conclusion: From this study, it will be concluded that crude extract of $C$. molle leaves has been shown promising antimalarial activity. The findings of this study may support the normal use of leaf as a part of the plant for malaria treatment.

Keywords: antimalarial, Combretum molle, crude extract, Plasmodium berghei, subacute toxicity

\section{Introduction}

Malaria can be a hemoparasitic disease, causing mortality and morbidity in children and adults. ${ }^{1,2}$ It is caused by Plasmodium species that invade, grow, and replicate in red blood cells. ${ }^{3,4}$ Its control requires prevention and prompt treatment with effective antimalarial drugs. ${ }^{5}$ It is among the foremost devastating and widespread tropical diseases and most prevalent in developing countries. ${ }^{6}$ Drug resistance of plasmodium species to available drugs causes a big threat to its control. ${ }^{7}$ WHO 2018 reported 219 million malaria cases worldwide and in 2017200 million malaria cases in Africa. ${ }^{8}$ Africa and India accounted for $47 \%$ of all malaria deaths globally. ${ }^{9}$ P. falciparum species are dominant in Africa and P.vivax infection is in South America and Southeast Asia. ${ }^{10}$ In pregnant, women P. falciparum causes infections because of parasite's ability to massively sequester in the placenta and compromised immune 
status, mainly during the first and second trimesters of pregnancy. ${ }^{11}$ About $60 \%$ of the Ethiopian population is in peril of malaria with major transmission seasons from June to December and remain liable for an enormous burden of morbidity and mortality. ${ }^{12,13}$ Extracts which show percentage of parasitemia suppression equal to or greater than $50 \%$ at doses of 100,250 , and $500 \mathrm{mg} / \mathrm{kg}$ per day in vivo antiplasmodial activity may be classified as excellent, good, and moderate, respectively. ${ }^{14}$

Combretum molle could be a small tree of 3-13 meters high, with a crooked trunk. It is an indigenous plant in Africa and one in all the important medicinal species of the family. ${ }^{15} \mathrm{C}$. molle is used to treat parasitic, protozoan, and other infectious diseases. ${ }^{16}$

The Fresh leaf is boiled in water and also the decoction is drunk by a cup of tea and doubtless leaves are the middle of intermediary metabolism leading to biologically active secondary metabolites. ${ }^{17,18}$ The in vitro cell culture (K562S human monocyte infected with $P$. falciparum W2) study had shown activity with an $\mathrm{IC}_{50}$ value of $7.9 \mu \mathrm{g} / \mathrm{mL}$ from $80 \%$ methanolic extract of leaves. Ethanolic $90 \%$ extract of leaves, root bark, or stem bark in vitro cell culture with $P$. falciparum $\mathrm{K} 1$ showed activity with an $\mathrm{IC}_{50}$ value of $4 \mu \mathrm{g} / \mathrm{mL} .{ }^{19}$ Stem bark in vitro cell culture (P. falciparum) of acetone fraction and methanol crude extract showed activity with $\mathrm{IC}_{50}$ values of $8.17 \mu \mathrm{g} / \mathrm{mL}$ and $1.25 \mu \mathrm{g} / \mathrm{mL}$, respectively. ${ }^{20,21} \mathrm{C}$. molle methanolic seed extract on four day suppressive test at 125 and $250 \mathrm{mg} / \mathrm{kg}$ /day showed 36.6 and $65.5 \%$ of parasitemia inhibition, respectively. ${ }^{22}$ In another study of methanolic steam bark extract at 100 , 2000 and $400 \mathrm{mg} / \mathrm{kg} /$ day showed $38.6,52.5$, and $59.7 \%$ of parasitemia inhibition, respectively. ${ }^{23}$

\section{The Rationale of the Study}

The leaves of Combretum molle are employed to treat malaria symptoms in Ethiopia, especially in Delanta and Amaro District. But the protection and efficacy is not scientifically proved. Our study was planned to determine subacute, acute oral toxicities and in vivo antimalarial effects of methanolic extract and solvent fractions of $C$. molle leaves in mice infected with $P$. berghei.

\section{Methods, Chemicals, Supplies and Materials}

Normal isotonic saline, absolute methanol (NICE chemicals, India), hexane (Blulux Laboratory, India), chloroform, 2\% Tween80 (Blulux Laboratory, India), Tri sodium citrate (Sheba pharmaceuticals, Ethiopia), 10\% Giemsa (AVONCHEM, United Kingdom), distilled water, ethanol $(70 \%, 80 \%, 90 \%)$ (NICE Chemicals, India), chloroquine phosphate tablet (Ethiopian pharmaceutical manufacturer, Ethiopia) ferric chloride (Fisher scientific CO., USA), sodium hydroxide (Super tech, India), hydrochloric acid (Blulux laboratories, India), sodium bicarbonate solution, $1 \%$ acid alcohol, sulfuric acid (Super tech, India), Wagner's reagent (Avishkar Lab Tech Chemicals, India), formalin, paraffin, xylene, hematoxylin and eosin, electrical balance (JA203P, Japan), gloves, $1 \mathrm{~mL}$ syringes, needles, hematocrit centrifuge and micro-hematocrit reader (Hettich, Germany), oral gavage, vials, rotary evaporator (Yamato scientific Company, Japan), permanent marker, cotton swab, vaccum freezer dryer (LABFREZ Instruments group company, FD-12MR, China), Whatman filters paper №1 (Whatman ${ }^{\circledR}$, England), collecting flask, stopwatch, microscope (Olympus CX 21F51, Japan), laboratory glass wares, dry oven (ABRON, India), refrigerator (Hitachi, Japan), microtome with blade, Canada valsum, frosted microscopic slide, cover slip.

\section{Plant Material}

Fresh leaves of Combretum molle were collected from "Tara Gedam", Libo Kemkem District, South Gondar Zone, Amhara region at a longitude and latitude of $12^{\circ}$ $07^{\prime} \mathrm{N} 37^{\circ} 47^{\prime} \mathrm{E}$ and an elevation of 1975 meters on December 13, 2018. The collected material was wrapped and covered with plastic sheets during transportation. The specimen of the plant was authenticated by Abiyu Enyew a botanist, in the department of biology, University of Gondar and was deposited in the herbarium with a voucher specimen (№ 001MAS) for future reference.

\section{Preparations of Crude Methanolic Extract}

Fresh leaves of $C$. molle were washed with water and shade dried, reduced to an appropriate size by hand compression. C. molle leaves powder 1500 grams was macerated in 9 liters of $80 \%$ methanol for 3 days with occasional shaking and filtered using thick layers of 40 mesh gauze and Whatman paper №1 twice. Second extraction was repeated after 72 hours of residue maceration and similar procedure was repeated another 72 hours later. The filtrates were combined and concentrated using a rotary evaporator at $40^{\circ} \mathrm{C}$ and water was removed by freeze dryer. Final yield was $287 \mathrm{~g}(19.13 \%)$ and stored in an airtight bottle in a refrigerator at $4^{\circ} \mathrm{C}$ until use. ${ }^{24}$ 


\section{Solvent Fractionation of Hydromethanolic Crude Extract}

Methanolic crude extract of $C$. molle leaves was fractionated with water, hexane, and chloroform. Methanolic crude extract $70 \mathrm{gm}$ was dissolved in $420 \mathrm{~mL}$ water. Then, equal volume of hexane was added to that. After gently shaken, the extract was allowed to settle and separated into two distinct layers in step with their density. The upper hexane layer was collected and also the identical procedure was repeated 3 times. After the gathering of hexane fraction of the extract, the water portion was fractionated with chloroform thrice with same procedure of hexane and also the underside chloroform layer was collected, leaving the aqueous fraction at the upper part. The filtrates of chloroform and hexane fractions were concentrated by rotary evaporator and dried by dry oven at $40^{\circ} \mathrm{C}$. The aqueous fraction was freeze in refrigerator overnight and was dried with lyophilizer. The proportion yield was calculated and stored at $4^{\circ} \mathrm{C}$ until use. ${ }^{25}$

\section{Phytochemical Screening}

The qualitative phytochemical screening tests were performed on $80 \%$ methanolic crude extract of C. molle leaves using standard chemicals and procedures which were utilized in previous researches. ${ }^{26-36}$

\section{Animals and Parasite}

Swiss albino mice weighing between 20-33 grams, 6-8 weeks old, and either sex and pellet diet were purchased from the Ethiopian public health institute (EPHI), Addis Ababa. The animals were kept in cages and housed with a typical animal house under a natural 12/12h light-dark cycle at room temperature and maintained on a pellet diet and free access to water. Before the experiment, they were acclimatized to the test environment for 1 week. The care and handling of mice were per international guidelines for the use and maintenance of experimental animals. $^{37,38}$

Chloroquine-sensitive malaria, $P$. berghei was obtained from EPHI in the traditional medicine research department Addis Ababa and transported by infecting the donor mice and maintained the parasite up to the actual procedure of the study.

\section{Acute Toxicity Test}

Five female mice, weighing between $20-28$ grams, 6-8 weeks old were kept for 2 days before dosing to acclimatize. One mouse was randomly taken to work out preliminary toxicity observation on free access to water but fasted for 4 hours, weighed and so, crude methanolic extract of C. molle leaves at $2000 \mathrm{mg} / \mathrm{kg}$ weight was administered by the oral route. Strict observation for half-hour and periodically for the first 24 hours, and observed for consecutive 14 days. Observation was majorly focused on physical and behavioral changes of the mouse. But preliminary toxicity observation of the mouse did not show any sign of toxicity for four days. The remaining 4 mice were dosed with methanolic crude extract of $C$. molle leaves at $2000 \mathrm{mg} / \mathrm{kg}$ and followed for 14 days. ${ }^{37-39}$

\section{Subacute Toxicity Test}

The subacute toxicity study was conducted on 24 healthy female mice divided randomly into four groups of six each. The negative control group treated with solvent $10 \mathrm{ml} / \mathrm{kg}$; the rest three groups got 100,200 , and $400 \mathrm{mg} / \mathrm{kg} /$ day of methanolic crude extract C. molle leaves orally for 28 days. The mice were observed every 2 hours for toxic signs and weighted weekly for 4 weeks. On the 29th day, mice were anesthetized with ketamine $80 \mathrm{mg} / \mathrm{kg}$ and sacrificed. Their Liver and kidneys were removed and weighed. ${ }^{37,40}$

\section{Tissue Processing}

Immediately removed liver and kidneys were placed in $10 \%$ formalin with phosphate-buffered solution overnight at temperature. After overnight fixation, the tissues were dehydrated with increased concentration of alcohol: $70 \%$, $80 \%, 90 \%$ for five and half an hour, then cleared with xylene for 7 hours. Finally, the tissues were impregnated for 6 hours. Then, tissue blocks were prepared by embedding with wax in an exceedingly square metal plate and labeled. Tissue blocks were sectioned with a thickness of $5 \mu \mathrm{m}$ with a rotary microtome. Strips of sections were gently lowered into the surface of a warm water bath at $40^{\circ} \mathrm{C}$ for sections to be floated, then mounted with coated egg albumin slides, and then the slides containing paraffin with a slide holder were placed in an oven with a temperature of $60^{\circ} \mathrm{C}$ for $10-15$ minutes until they become freed from wax. Sectioned tissues were placed in xylene to deparaffinize and hydrated with decreasing alcohol concentrations, then stained with Hematoxylene for 5 minutes and counterstained by using eosin for 1 minute. After washing in water, the sections were dehydrated with increased alcohol concentration and cleared with xylene. Finally, sections were mounted on microscopic slides by 
using Canada balsam mount and canopy slips and examined the tissue under the light microscope with different objectives were taken a photograph automatically with magnification of $\mathrm{x} 40 .{ }^{41-43}$

\section{Pharmacologic Screening (4-Day Suppressive Test)}

In vivo evaluation of methanolic crude extract and solvent fractions of $C$. molle leaves antimalarial activity on $P$. berghei. Donor $P$. berghei infected Swiss albino mice (parasitemia of roughly 30\%) were sacrificed by decapitation and, then blood was collected through cardiac puncture with a sterile disposable needle and syringe. The blood was diluted with sterile normal saline $0.9 \%$ in water so $0.2 \mathrm{~mL}$ of blood contained about $10^{7}$ infected RBCs and mice were infected by $0.2 \mathrm{~mL}$ blood suspension intraperitoneally which was expected to produce steadily rising consistent infection of the required intensity in mice. $^{26}$ For methanolic crude extract mice were randomly divided into five groups of six each, weighed, and maintained with pellet diet. Three different doses of methanolic crude extract (Group I (100mg/kg/day), II $(200 \mathrm{mg} / \mathrm{kg} /$ day), III (400mg/kg/day), Group IV received chloroquine base $25 \mathrm{mg} / \mathrm{kg} /$ day (positive control), and group $\mathrm{V}$ received a solvent $(10 \mathrm{~mL} / \mathrm{kg} /$ day $)$ which contained $3 \mathrm{~mL}$ of $96 \%$ ethanol $+7 \mathrm{~mL}$ of Tween $80+90 \mathrm{~mL}$ of water (negative control)). ${ }^{44,45}$ The doses of methanolic crude extract and solvent fractions of $C$. molle leaves were adjusted from the safest dose of acute toxicity study $(2000 \mathrm{mg} / \mathrm{kg})$ and were $5 \%(100 \mathrm{mg} / \mathrm{kg}), 10 \%(200 \mathrm{mg} / \mathrm{kg})$, and $20 \%(400 \mathrm{mg} / \mathrm{kg})$ from lower to higher doses, respectively. For solvent fractions, mice were randomly divided into eight groups of six each, weighed, and maintained with pellet diet. Three different doses of chloroform fraction (Group I(100mg/ $\mathrm{kg} /$ day), II (200mg/kg/day), III (400mg/kg/day)), hexane fraction group IV (100mg/kg/day), V(200mg/kg/day), VI (400mg/kg/day), aqueous fraction group VII $(100 \mathrm{mg} / \mathrm{kg} /$ day), VIII (200mg/kg/day), IX (400mg/kg/day), Group X received chloroquine base $25 \mathrm{mg} / \mathrm{kg} /$ day (positive control), and group XI received a solvent $(10 \mathrm{~mL} / \mathrm{kg} / \mathrm{day}),{ }^{4,45}$ and administered orally using oral gavage after 3 hours of parasite inoculation.

\section{Determination of Parasitemia}

On day 4 (96 hours) post-infection a drop of blood was collected from the mice by vein section of the tail and transferred onto the edge of a microscopic slide and drawn evenly across the second slide to create a thin blood film and allowed to dry at room temperature, fixed with methanol, stained with $10 \%$ Giemsa stain for quarter-hour. For every slide, five fields were viewed microscopically with oil immersion (1000 x magnification). The number of PRBCs and uninfected RBCs counted and thus the percent parasitemia was calculated. ${ }^{4,45}$ The weight, temperature, packed cell volume, and mean survival time were determined for every group arithmetically. ${ }^{45}$

Percent parasitemia was calculated according to the following formula: ${ }^{46,47}$

$\%$ paristemia $=\frac{\text { Total number of } \mathrm{PRBC}}{\text { Total number of } \mathrm{RBC}} \times 100$ where $\mathrm{PRBC}:$ Parasitized red blood cells

RBC: red blood cells.

Average percentage of parasitemia suppression was calculated as follows:

Average $\%$ of paristemia supression

$$
\begin{aligned}
= & \frac{\text { Av. } \% \text { of parasit. in control }- \text { Av. } \% \text { of parasitemia in test }}{\text { Av. } \% \text { of parasitemia in control }} \\
\times 100 & \text { A }
\end{aligned}
$$

Av $=$ average

\section{Rane's (Curative) Test}

Evaluation of the curative potential of methanolic crude extract and chloroform fraction of $C$. molle leaves was disbursed in line with the strategy described by curative methods44. On day 0 , standard inocula of about $10^{7}$ infected erythrocytes were inoculated in mice intraperitoneally and randomly divided into eight groups and 6 mice in each group, weighed and maintained in a standard diet. Seventy-two hours later three different doses of methanolic crude extract of $C$. molle group I( $100 \mathrm{mg} / \mathrm{kg} / \mathrm{day})$, II (200mg/kg/day), III (400mg/kg/day) and chloroform fraction of C. molle group IV (100mg/kg/day), V(200mg/kg/ day), VI (400mg/kg/day), Group VII received chloroquine base $25 \mathrm{mg} / \mathrm{kg} /$ day (positive control), and group VIII received a solvent $(10 \mathrm{~mL} / \mathrm{kg} /$ day $)$ which contained $3 \mathrm{~mL}$ of $96 \%$ ethanol $+7 \mathrm{~mL}$ of Tween $80+90 \mathrm{~mL}$ of water (negative control), ${ }^{44,45}$ and administered orally using oral gavage once daily for 5 days. Giemsa stained thin blood film was prepared from the tail of every mouse daily for 5 days (day 3, 4, 5, 6, and 7) to determine the parasitemia level. The weight, body temperature, packed cell volume, and mean survival time were determined for every group arithmetically. $^{45}$ 


\section{The Repository (Prophylactic) Test}

In prophylactic test before infection, mice were randomly divided into eight groups and six mice in each group, weighed and maintained in an exceedingly standard diet. Three different doses of methanolic crude extract of $C$. molle group I $(100 \mathrm{mg} / \mathrm{kg} /$ day $)$, II $(200 \mathrm{mg} / \mathrm{kg} /$ day $)$, III (400mg/ $\mathrm{kg} /$ day), chloroform fraction of C. molle group IV $(100 \mathrm{mg} / \mathrm{kg} /$ day $), \quad \mathrm{V}(200 \mathrm{mg} / \mathrm{kg} /$ day $)$, VI $(400 \mathrm{mg} / \mathrm{kg} /$ day), group VII received chloroquine base $25 \mathrm{mg} / \mathrm{kg} /$ day (positive control), and group VIII received a solvent $(10 \mathrm{~mL} / \mathrm{kg} / \mathrm{day})$ which contained $3 \mathrm{~mL}$ of $96 \%$ ethanol + $7 \mathrm{~mL}$ of Tween $80+90 \mathrm{~mL}$ of water (negative control), ${ }^{44,45}$ and administered orally using oral gavage once daily for 3 days. On the fourth day, a typical inoculum of Plasmodium berghei containing $\sim 1 \times 10^{7}$ infected erythrocytes was administered intraperitoneally to every mouse. On the seventh day of infection (72 hours later), thin blood smears (Giemsa stained) were prepared from the tail of every mouse by vein section. Percentage parasitemia, percentage parasitemia inhibition, weight, body temperature, packed cell volume, and mean survival time were determined for every group arithmetically. ${ }^{44}$

\section{Determination of Mean Survival Time}

Any death recorded within 28 days of the study period to evaluate the crude methanolic extract and solvent fractions effect for improvement in survival days. The animals were maintained on standard pellet. ${ }^{45}$

$$
\text { Mean survival times }=\frac{\begin{array}{l}
\text { Sum of survival times } \\
\text { for all mice a group }(\text { in days })
\end{array}}{\begin{array}{l}
\text { Total number of } \\
\text { mice in this group }
\end{array}}
$$

Packed cell volume (PCV) was measured to predict the effectiveness of the test extract and chloroform fraction in preventing hemolysis resulting from increasing parasitemia associated with malaria. Heparinized capillary tubes were used for the gathering of blood from the tail of each mouse. The capillary tubes were stuffed with blood up to three-fourth of their volume and sealed at the dry end with sealing clay. The tubes were then placed in a microhematocrit centrifuge, with the sealed end outwards and centrifuged for 5 minutes at $12,000 \mathrm{rpm}$. The tubes were taken out of the centrifuge and PCV resolves employing a regular Micro-Hematocrit Reader. ${ }^{48,49}$
Percent change PCV $=\frac{\text { PCV day } 4-\text { PCV day } 0}{\text { PCV day } 4} \mathrm{X} 100$

where, $\mathrm{PCV}=$ Packed cell volume.

\section{Monitoring of Weight and Temperature Changes}

In Peter's test the weight was measured 1 hour before parasite infection on Day-0 (D0) and on day-4 (D4) after treatment completion, while the rectal temperature was measured 1 hour before and 3 hours after parasite infection then consecutively for 4 days to observe the consequence of methanolic crude extract and solvent fractions of $C$. molle leaves on mice's body temperature. For Rane's test, the body weight and temperature were measured 3 hours before infection on day-0 (D0) and consecutively for 5 days during the treatment period to work out the effect of methanolic crude extract and chloroform fraction of $C$. molle leaves on $P$. berghei infected mice. For the prophylactic test, the body weight and temperature were measured 3 hours before infection on day-0 (D0) and consecutively from D4-D7 after infection period to see the effect of methanolic crude extract and chloroform fraction of $C$. molle leaves on $P$. berghei infected mice. ${ }^{50}$

$$
\begin{aligned}
\text { Body weight change }= & \text { Body weight day } 4 \\
& - \text { body weight day } 0
\end{aligned}
$$

$$
\begin{aligned}
& \text { body weight day } 4 \\
& \text { Percent body weight change }=\frac{- \text { Body weight day } 0}{\text { Body weight day } 4} \times 100
\end{aligned}
$$

\section{Data Quality Control}

Data quality was assured by using randomization during the grouping of experimental animals. Unique codes were used for all frosted microscopic slides during the preparation of blood smears. Parasitized and noninfected red blood cells were counted blindly by laboratory professional.

\section{Data Analysis}

The results of the study were expressed as mean \pm standard error of the mean $(\mathrm{M} \pm \mathrm{SEM})$. Comparison of parasitemia and statistical significance determined by one-way ANOVA (a repeated measure of research of variance) 
descriptive statistics followed by post hoc Tukey HSD tests for multiple comparisons and paired $t$-test was employed to test the significance of the difference between initial and final results within the identical and in between groups using SPSS for window (Version 24.0) statistical package. All data were analyzed at a $95 \%$ confidence interval and $\mathrm{P}<0.05$ was considered statistically significant. $^{45}$

\section{Results}

\section{Phytochemical Screening}

The phytochemical screening of $80 \%$ methanolic crude extract of C. molle leaves indicated the presence of alkaloids, cardiac glycosides, flavonoids, phenols, saponins, tannins, and terpenoids.

\section{Acute Oral Toxicity Test}

The acute oral toxicity study showed that no death and any sign of toxicity to mice with an oral dose of $2000 \mathrm{mg} / \mathrm{kg}$ of the methanolic crude extract of $C$. molle leaves observed for 14 days. Here it will be deduced that the lethal dose fifty $\left(\mathrm{LD}_{50}\right)$ was above $2000 \mathrm{mg} / \mathrm{kg}$ weight. The bioactive constituents of the plant are safe to be used while it is difficult to extrapolate the result to humans.

\section{Subacute Toxicity Study}

The methanolic crude extract of $C$. molle leaves was administered for consecutive 28 days at doses of 100 , 200 and $400 \mathrm{mg} / \mathrm{kg} /$ day showed a mean loss of 1.01 $\pm 0.84 \mathrm{~g}(\mathrm{p}=0.013), 1.23 \pm 0.86 \mathrm{~g}(\mathrm{P}=0.012)$, and 0.45 $\pm 0.66 \mathrm{~g}(\mathrm{P}=0.065)$, respectively. Mice treated with solvent gain a mean weight of $3.05 \pm 0.95 \mathrm{~g}$ (See Table 1 ).

The mean weight of kidney in subacute toxicity test of methanolic crude extract of C. molle leaves at 100, 200, and $400 \mathrm{mg} / \mathrm{kg} /$ day was $0.17 \pm 0.02 \mathrm{~g}(\mathrm{P}=0.945), 0.17 \pm 0.02 \mathrm{~g}$ $(\mathrm{P}=0.945)$, and $0.13 \pm 0.01 \mathrm{~g}(\mathrm{P}=0.180)$, respectively. There was no significant difference compared to negative control group (0.18 $\pm 0.01 \mathrm{~g}$ ) (See Table 2).

The mean weight of liver in subacute toxicity test of methanolic crude extract of $C$. molle leaves at 100, 200, and $400 \mathrm{mg} / \mathrm{kg} /$ day was $1.80 \pm 0.09 \mathrm{~g}(\mathrm{P}=0.242), 1.65 \pm 0.10 \mathrm{~g}$ ( $\mathrm{P}=0.028)$, and $1.55 \pm 0.10 \mathrm{~g}(\mathrm{P}=0.008)$, respectively. At doses $200 \mathrm{mg} / \mathrm{kg}$ and $400 \mathrm{mg} / \mathrm{kg}$ produced significant differences compared to negative control group ( $p<0.05$ and $\mathrm{p}<0.01$ ), respectively, compared to the negative control $2.05 \pm 0.08 \mathrm{~g}$ (See Table 2).
The mean weight of kidney in subacute toxicity test of methanolic crude extract of $C$. molle leaves at 100, 200, and $400 \mathrm{mg} / \mathrm{kg} /$ day was $0.17 \pm 0.02 \mathrm{~g}(\mathrm{P}=0.945), 0.17 \pm 0.02 \mathrm{~g}$ $(\mathrm{P}=0.945)$, and $0.13 \pm 0.01 \mathrm{~g}(\mathrm{P}=0.180)$, respectively. There was no significant difference compared to negative control group $(0.18 \pm 0.01 \mathrm{~g})$ (See Table 2).

The mean weight of liver in subacute toxicity test of methanolic crude extract of $C$. molle leaves at 100, 200, and $400 \mathrm{mg} / \mathrm{kg} /$ day was $1.80 \pm 0.09 \mathrm{~g}(\mathrm{P}=0.242), 1.65 \pm 0.10 \mathrm{~g}$ $(\mathrm{P}=0.028)$, and $1.55 \pm 0.10 \mathrm{~g}(\mathrm{P}=0.008)$, respectively. At doses $200 \mathrm{mg} / \mathrm{kg}$ and $400 \mathrm{mg} / \mathrm{kg}$ produced significant differences compared to negative control group $(\mathrm{p}<0.05$ and $\mathrm{p}<0.01$ ), respectively, compared to the negative control $2.05 \pm 0.08 \mathrm{~g}$ (See Table 2).

\section{Effects of Methanolic Extract of C. molle Leaves on Histology of Liver Tissues}

Microscopic examination of liver sections of mice treated with solvent $10 \mathrm{~mL} / \mathrm{kg} /$ day (Figure $1 \mathrm{~A}$ ), methanolic crude extract of C. molle leaves at $100 \mathrm{mg} / \mathrm{kg} /$ day (Figure 1B), methanolic crude extract of C. molle leaves at $200 \mathrm{mg} / \mathrm{kg} /$ day (Figure 1C), and methanolic crude extract of C. molle leaves at $400 \mathrm{mg} / \mathrm{kg} /$ day (Figure 1D) showed the conventional architecture of structural units of the hepatic lobules, formed by cords of hepatocytes separated by hepatic sinusoids. The central vein and portal area containing branches of arterial blood vessel duct and portal veins were maintained with their normal appearance just like the negative control (See Figure 1).

\section{Effects of Methanolic Extract of $C$. molle Leaves on Histology of Kidney Tissues}

Microscopic examination of kidney sections of mice treated with solvent $10 \mathrm{~mL} / \mathrm{kg}$ /day (Figure $2 \mathrm{~A}$ ), methanolic crude extract of $C$. molle leaves at $100 \mathrm{mg} / \mathrm{kg} /$ day (Figure 2B), methanolic crude extract of $C$. molle leaves at $200 \mathrm{mg} / \mathrm{kg} /$ day (Figure 2C), and methanolic crude extract of C. molle leaves at $400 \mathrm{mg} / \mathrm{kg} /$ day (Figure 2D) showed the traditional architecture of structural units of the Glomerulus, Urinary space, Proximal convoluted tubule, Distal convoluted tubule, Macula densa, Vascular pole were maintained with their normal appearance the same as the negative control (See Figure 2).

\section{Antimalarial Suppressive Test}

Antimalarial suppressive test of methanolic crude extract of $C$. molle leaf and chloroquine base against $P$. berghei 
Table I Body Weight of Mice in Subacute Toxicity Study of Methanolic Crude Extract of C. molle Leaves

\begin{tabular}{|l|l|l|l|l|l|l|}
\hline \multirow{2}{*}{ Treatment Group } & \multicolumn{5}{l}{ Body weight (g) } \\
\cline { 2 - 7 } & Initial Weight & After I Week & After 2 Weeks & After 3 Weeks & After 4 Weeks & Body Weight Change \\
\hline Controll $0 \mathrm{ml} / \mathrm{kg}$ & $28.44 \pm 0.97$ & $31.52 \pm 0.72$ & $31.45 \pm 0.68$ & $31.47 \pm 0.54$ & $31.48 \pm 0.62$ & $3.05 \pm 0.95$ \\
CMI00mg/kg & $26.46 \pm 1.27$ & $28.29 \pm 1.66$ & $28.65 \pm 1.27$ & $26.42 \pm 1.48$ & $25.45 \pm 2.04$ & $-1.01 \pm 0.84^{\mathrm{a}, \mathrm{b}}$ \\
CM $200 \mathrm{mg} / \mathrm{kg}$ & $27.31 \pm 0.68$ & $27.11 \pm 1.69$ & $24.76 \pm 1.26$ & $26.68 \pm 1.76$ & $25.89 \pm 1.52$ & $-1.23 \pm 0.86^{\mathrm{a}, \mathrm{b}}$ \\
CM400mg/kg & $27.47 \pm 0.84$ & $27.43 \pm 1.04$ & $24.60 \pm 0.63$ & $26.70 \pm 1.18$ & $26.73 \pm 0.90$ & $-0.45 \pm 0.66$ \\
\hline
\end{tabular}

Notes: Results presented as mean \pm SEM; $(n=6)$. ${ }^{a}$ Compared to negative control; ${ }^{b} \mathrm{P}<0.05$.

Abbreviation: $\mathrm{CM}$, crude methanolic extract of $C$. molle leaves.

Table 2 Absolute Organ Weight of Mice in Subacute Toxicity Study of Methanolic Crude Extract of $C$. molle Leaves

\begin{tabular}{|l|l|l|}
\hline \multirow{2}{*}{ Treatment Group } & Mean Weight (Gram) & Liver \\
\cline { 2 - 3 } & Kidney & $2.05 \pm 0.08$ \\
\hline Solvent $10 \mathrm{ml} / \mathrm{kg}$ & $0.18 \pm 0.01$ & $1.80 \pm 0.09$ \\
$\mathrm{CM} 100 \mathrm{mg} / \mathrm{kg}$ & $0.17 \pm 0.02$ & $1.65 \pm 0.10^{\mathrm{a}, \mathrm{b}}$ \\
$\mathrm{CM} 200 \mathrm{mg} / \mathrm{kg}$ & $0.17 \pm 0.02$ & $1.55 \pm 0.10^{\mathrm{a}, \mathrm{c}}$ \\
$\mathrm{CM} 400 \mathrm{mg} / \mathrm{kg}$ & $0.13 \pm 0.01$ & 1.01 \\
\hline
\end{tabular}

Notes: Data are expressed as mean \pm SEM $[n=6] .{ }^{a}$ Compared to negative control; ${ }^{b} p<0.05 ;{ }^{c} p<0.01$.

Abbreviation: CM, methanolic crude extract of Combretum molle leaves.

infected mice resulted in reduced parasite load as compared to their respective negative control group.

Antimalarial suppressive test of methanolic crude extract at 100,200 and $400 \mathrm{mg} / \mathrm{kg} /$ day and chloroquine base $25 \mathrm{mg} /$ $\mathrm{kg}$ /day showed $33.08,45.36,76.17$ and $95.72 \%$ parasitemia inhibition, respectively, at day-4 (See Table 3).

$P$. berghei infected mice treated with methanolic crude extract of C. molle leaves at $100,200,400 \mathrm{mg} / \mathrm{kg} / \mathrm{day}$, chloroquine base $25 \mathrm{mg} / \mathrm{kg} /$ day and solvent $10 \mathrm{~mL} / \mathrm{kg} /$ day showed $7.00 \pm 0.97 \quad(\mathrm{P}=0.988), \quad 9.83 \pm 1.92 \quad(\mathrm{P}=0.571), \quad 13.83 \pm 3.20$ $(\mathrm{P}=0.049), 27.00 \pm 2.03(\mathrm{P}<0.001)$, and $5.67 \pm 0.49$ days of mean survival time, respectively, at day-4 (See Table 3).

Antimalarial suppressive test of chloroform fraction of C. molle leaves at 100,200 and $400 \mathrm{mg} / \mathrm{kg} /$ day showed $52.93,54.32$, and $67.73 \%$ parasitemia inhibition, respectively, at day- 4 . The hexane fraction of $C$. molle leaves at 100,200 and $400 \mathrm{mg} / \mathrm{kg} /$ day showed 23.61, 27.62, and $44.97 \%$ parasitemia inhibition, respectively, at day- 4 . The aqueous fraction of $C$. molle leaves at 100, 200, and $400 \mathrm{mg} / \mathrm{kg} / \mathrm{day}$ and Chloroquine base at $25 \mathrm{mg} / \mathrm{kg} / \mathrm{day}$ showed $29.48,46.16,51.13$, and $97.80 \%$ parasitemia inhibition, respectively, at day-4 (See Table 4).

$P$. berghei infected mice treated with chloroform fraction of $C$. molle leaves at $100,200,400 \mathrm{mg} / \mathrm{kg} /$ day showed $6.50 \pm 0.67 \quad(\mathrm{P}=0.993), \quad 8.17 \pm 1.05 \quad(\mathrm{P}=0.705), 12.83 \pm 2.75$ $(\mathrm{P}=0.025)$, hexane fraction of $C$. molle leaves at 100 ,
200, 400mg/kg/day showed 5.83 $\pm 0.54(\mathrm{P}=1.000), 6.50$ $\pm 0.76(\mathrm{P}=0.969), 8.33 \pm 1.23(\mathrm{P}=0.436)$, aqueous fraction of C. molle leaves at $100,200,400 \mathrm{mg} / \mathrm{kg} /$ day showed 6.83 $\pm 0.70 \quad(\mathrm{P}=0.915), \quad 8.33 \pm 0.84 \quad(\mathrm{P}=0.813), \quad 10.83 \pm 1.78$ $(\mathrm{P}=0.393)$, Chloroquine base at $25 \mathrm{mg} / \mathrm{kg} /$ day showed $29.50 \pm 0.34 \quad(\mathrm{P}<0.001)$ and negative control $5.67 \pm 0.56$ days of mean survival time, respectively, at day-4 (See Table 4).

\section{Effect of Methanolic Crude Extract of $C$. molle Leaves on Body Weight of $P$. berghei Infected Mice}

Plasmodium berghei infected mice treated with crude methanolic crude extract of C. molle leaves at 100, 200, and $400 \mathrm{mg} / \mathrm{kg}$ loss $3.24 \pm 0.84 \% \quad(\mathrm{p}=418), \quad 7.81 \pm 2.74 \%$ $(\mathrm{p}=1.000), 6.73 \pm 3.28 \% \quad(\mathrm{p}=982)$, chloroquine base at $25 \mathrm{mg} / \mathrm{kg} /$ day gain $0.55 \pm 0.34 \%(\mathrm{P}=0.083)$ of weight and mice treated with solvent loss $8.29 \pm 1.24 \%$ change of weight, respectively, at day-4 (See Table 5).

\section{Effect of Solvent Fractions of $C$. molle Leaves on Body Weight of $P$. berghei Infected Mice}

Plasmodium berghei infected mice treated with chloroform fraction of C. molle leaves at 100, 200, and 400mg/ 


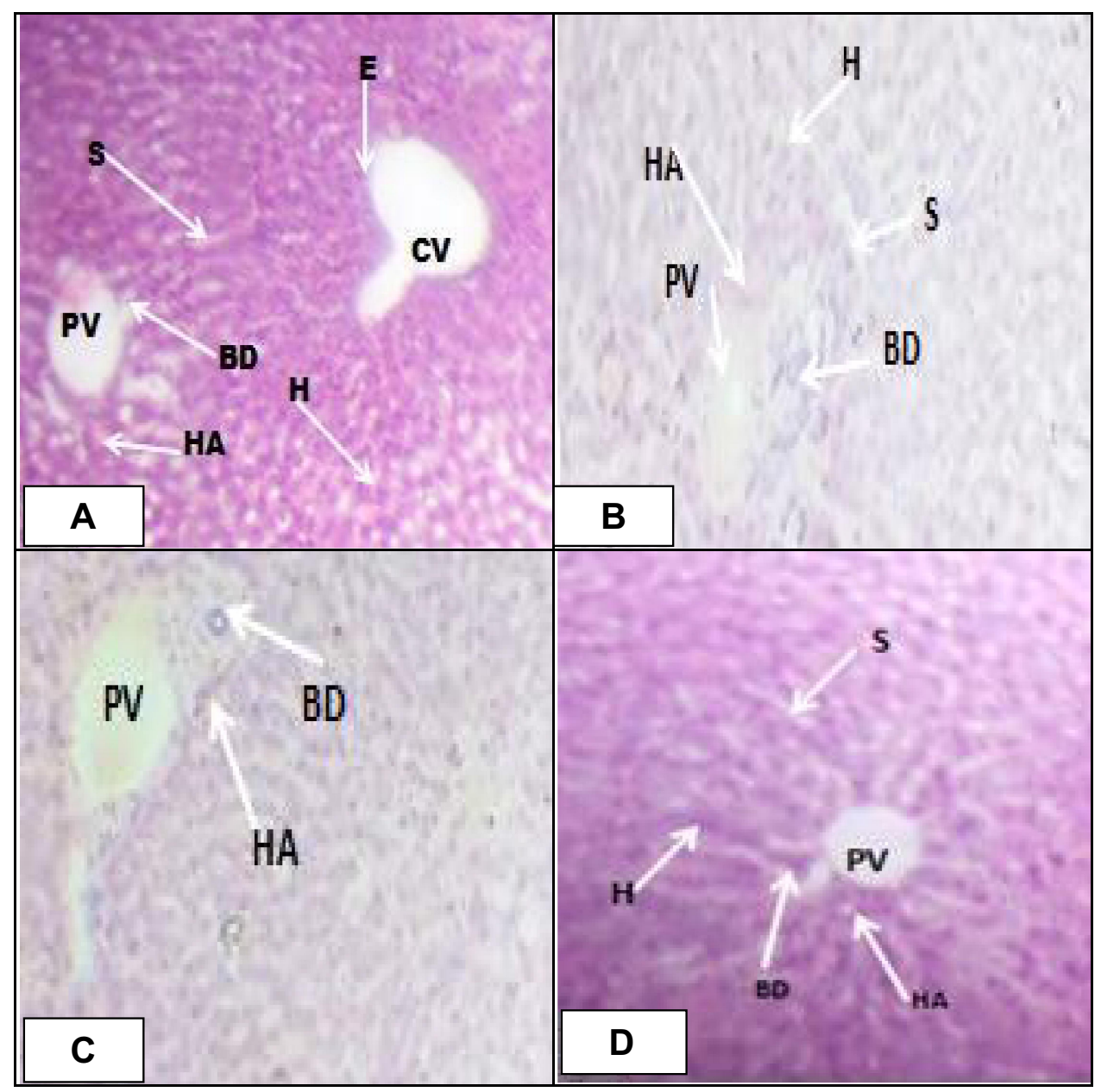

Figure I Microscopic architectures of liver after histopathological procedure $(\mathbf{A}=$ Negative control, B=100mg/kg, C=200mg/kg, and $\mathbf{D}=400 \mathrm{mg} / \mathrm{kg})$ of $\mathrm{methanolic} \mathrm{crude}$ extract of $C$. molle leaves.

Abbreviations: BD, bile duct; CV, central vein; E, endothelial cells; HA, hepatic artery; $\mathrm{H}$, hepatocytes; S, sinusoids; PV, portal vein.

$\mathrm{kg}$ loss $6.29 \pm 2.24 \% \quad(\mathrm{p}=0.934), 5.90 \pm 1.19 \% \quad(\mathrm{p}=0.974)$, hexane fraction of $C$. molle leaves at 100, 200, and $400 \mathrm{mg} / \mathrm{kg} \quad$ loss $2.86 \pm 2.14 \% \quad(\mathrm{p}=0.978), \quad 1.95 \pm 3.70 \%$ ( $\mathrm{p}=0.908), 1.79 \pm 1.04 \%(\mathrm{p}=0.890)$, aqueous fraction of $C$. molle leaves at 100,200 , and $400 \mathrm{mg} / \mathrm{kg}$ loss $0.87 \pm 1.35 \%$ $(\mathrm{p}=0.281), 1.23 \pm 1.15 \%(\mathrm{p}=0.376), 0.77 \pm 0.87 \%(\mathrm{p}=0.256)$, and chloroquine base at $25 \mathrm{mg} / \mathrm{kg}$ /day gain $4.78 \pm 1.20 \%$ ( $\mathrm{P}<0.001)$ of weight and mice treated with solvent loss $4.62 \pm 1.78 \%$ of body weight, respectively, at day-4 (See Table 6).

P. berghei infected mice treated with methanolic crude extract of $C$. molle leaves at 100, 200, 400mg/ $\mathrm{kg} /$ day showed $0.88 \pm 1.01 \% \quad(\mathrm{P}=0.384), \quad 0.78 \pm 0.56 \%$ $(\mathrm{P}=0.014), 0.75 \pm 0.86 \%(\mathrm{P}=0.317)$, Chloroquine base at $25 \mathrm{mg} / \mathrm{kg} /$ day showed $0.04 \pm 0.18 \%(\mathrm{P}=0.087)$ and negative control $2.67 \pm 0.55 \%$ change in body temperature, respectively, at day-4 (See Table 7).
P. berghei infected mice treated with chloroform fraction of $C$. molle leaves at $100,200,400 \mathrm{mg} / \mathrm{kg} /$ day showed 3.07 $\pm 0.95 \% \quad(\mathrm{P}=0.663), \quad 2.91 \pm 0.51 \% \quad(\mathrm{P}=0.556), \quad 1.00 \pm 0.23 \%$ ( $\mathrm{P}=0.008)$. Hexane fraction of C. molle leaves at 100, 200, $400 \mathrm{mg} / \mathrm{kg} /$ day showed $3.75 \pm 0.99 \%$ ( $\mathrm{P}=991), 1.67 \pm 0.46 \%$ $(\mathrm{P}=0.164), 1.81 \pm 1.05 \%(\mathrm{P}=0.204)$. Aqueous fraction of $C$. molle leaves at $100,200,400 \mathrm{mg} / \mathrm{kg} /$ day showed $2.33 \pm 1.60 \%$ $(\mathrm{P}=0.603), 2.82 \pm 1.02 \%(\mathrm{P}=0.814), 0.19 \pm 0.30 \%(\mathrm{P}=0.038)$, Chloroquine base at $25 \mathrm{mg} / \mathrm{kg}$ /day showed $0.28 \pm 0.17 \%$ $(\mathrm{P}=0.001)$ and negative control $10 \mathrm{~mL} / \mathrm{kg} /$ day $4.25 \pm 0.83 \%$ change in body temperature, respectively, at day-4 (See Table 8).

P. berghei infected mice treated with methanolic crude extract of C. molle leaves at $100,200,400 \mathrm{mg} / \mathrm{kg} /$ day showed $3.97 \pm 1.45 \% \quad(\mathrm{P}=0.894), 2.53 \pm 0.97 \% \quad(\mathrm{P}=0.275)$, $1.75 \pm 0.82 \%(\mathrm{P}=0.067)$, Chloroquine base at $25 \mathrm{mg} / \mathrm{kg} /$ day showed $1.77 \pm 0.36 \% \quad(\mathrm{P}=0.053)$ and negative control 


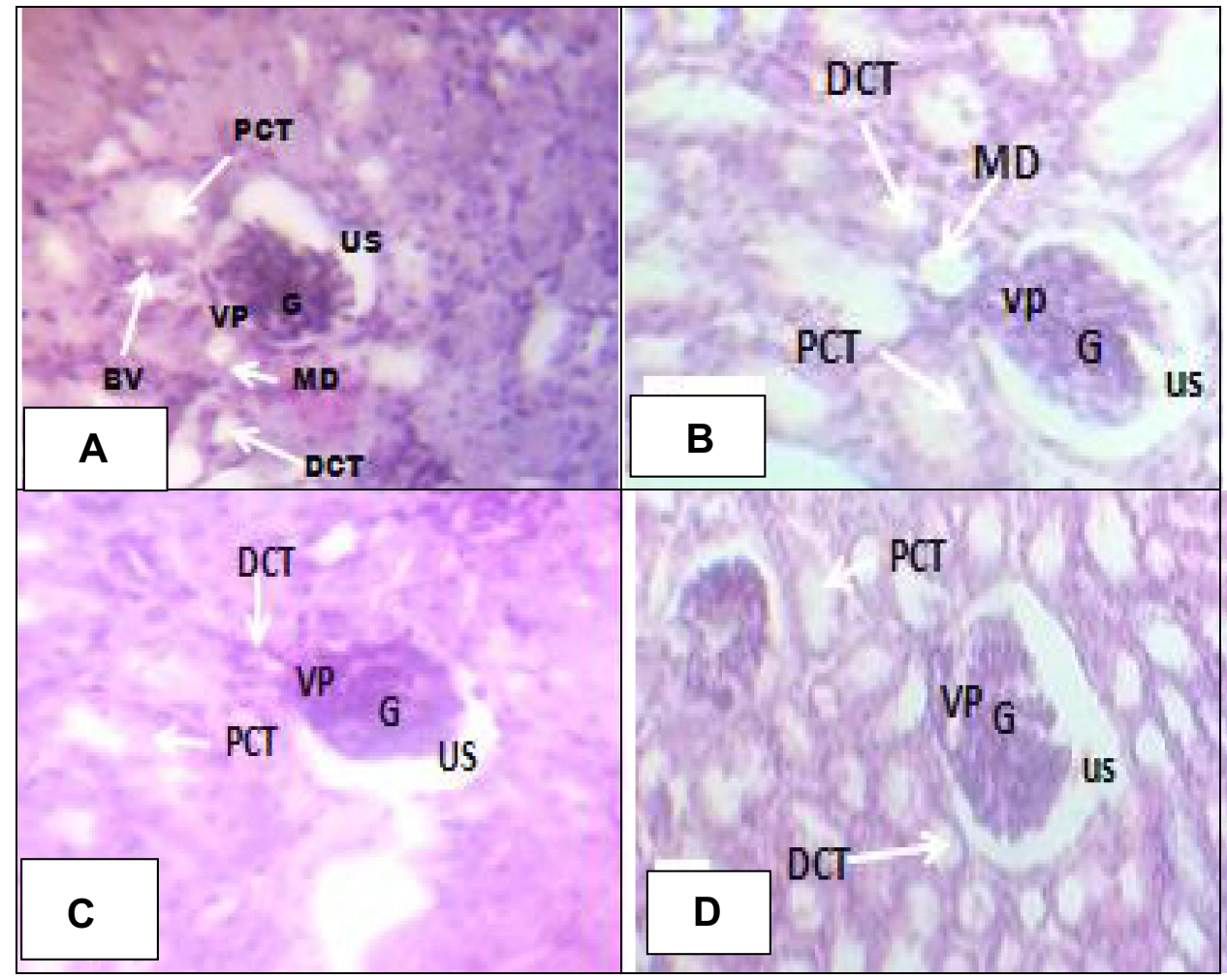

Figure 2 Microscopic architectures of kidney after histopathological procedure (A) Negative control, (B) $100 \mathrm{mg} / \mathrm{kg},($ C) $200 \mathrm{mg} / \mathrm{kg}$ and (D) $400 \mathrm{mg} / \mathrm{kg}$ of methanolic crude extract of $C$. molle leaves.

Abbreviations: G, glomerulus; BV, blood vessel; US, urinary space; PCT, proximal convoluted tubule; DCT, distal convoluted tubule; MD, macula densa; VP, vascular pole.

(solvent $10 \mathrm{~mL} / \mathrm{kg} /$ day) $5.08 \pm 0.71 \%$ change in packed cell volume, respectively, at day-4 (See Table 9).

$P$. berghei infected mice treated with chloroform fraction of $C$. molle leaves at $100,200,400 \mathrm{mg} / \mathrm{kg} /$ day showed 12.24 $\pm 8.12 \% \quad(\mathrm{P}=0.963), \quad 1.71 \pm 0.58 \% \quad(\mathrm{P}=0.818), \quad 3.07 \pm 2.06 \%$ $(\mathrm{P}=0.382)$. Hexane fraction of C. molle leaves at 100, 200, $400 \mathrm{mg} / \mathrm{kg} /$ day showed $4.72 \pm 0.79 \%(\mathrm{P}=207), 4.46 \pm 1.35 \%$ $(\mathrm{P}=0.133), 3.52 \pm 1.48 \%(\mathrm{P}=0.051)$. Aqueous fraction of $C$. molle leaves at $100,200,400 \mathrm{mg} / \mathrm{kg} /$ day showed $5.42 \pm 1.18 \%$ $(\mathrm{P}=0.349), 4.40 \pm 1.43 \%(\mathrm{P}=0.074), 1.86 \pm 0.48 \%(\mathrm{P}=0.002)$, Chloroquine base at $25 \mathrm{mg} / \mathrm{kg} /$ day showed $0.32 \pm 0.32 \%$
$(\mathrm{P}<0.001)$ and negative control $8.36 \pm 0.91 \%$ change in packed cell volume, respectively, at day-4 (See Table 10).

$P$. berghei infected mice treated with methanolic crude extract of $C$. molle leaves in curative test at 100, 200 and $400 \mathrm{mg} / \mathrm{kg} /$ day showed $43.3,62.98$, and $68.48 \%$ parasitemia inhibition, respectively. Chloroform fraction of $C$. molle leaf at 100,200 , and $400 \mathrm{mg} / \mathrm{kg}$ and chloroquine base at $25 \mathrm{mg} / \mathrm{kg} / \mathrm{day}$ showed $42.78 \%, 55.29 \%, 69.22 \%$, and $99.05 \%$ parasitemia inhibition, respectively, and thus the results were highly significant $(\mathrm{P}<0.001)$ compared to the negative control group at day-7 see Table 11).

Table 3 Mean Percent Parasitemia, Mean Percent Parasitemia Inhibition, and Mean Survival Time of $P$. berghei Infected Mice Treated with Methanolic Crude Extract of $C$. molle Leaves in the 4-Day Suppressive Test

\begin{tabular}{|c|c|c|c|}
\hline Extract/Fraction & $\%$ Parasitemia & \% Parasitemia Inhibition & Mean Survival Time (Days) \\
\hline $\mathrm{CON} / 0 \mathrm{ml} / \mathrm{kg}$ & $33.40 \pm 2.43$ & 0 & $5.67 \pm 0.49$ \\
\hline $\mathrm{CMI} 00 \mathrm{mg} / \mathrm{kg}$ & $22.35 \pm 1.76^{\mathrm{a}, \mathrm{d}, \mathrm{g}, \mathrm{e}, \mathrm{h}}$ & 33.4 & $7.00 \pm 0.97^{e, h}$ \\
\hline $\mathrm{CM} 200 \mathrm{mg} / \mathrm{kg}$ & $18.25 \pm 2.27^{\mathrm{a}, \mathrm{e}, \mathrm{h}, \mathrm{d}, \mathrm{f}}$ & 45.36 & $9.83 \pm 1.92^{\mathrm{e}, \mathrm{h}}$ \\
\hline $\mathrm{CM} 400 \mathrm{mg} / \mathrm{kg}$ & $7.96 \pm 2.26^{\mathrm{a}, \mathrm{h}, \mathrm{b}, \mathrm{g}, \mathrm{c}, \mathrm{f}}$ & 76.17 & $13.83 \pm 3.20^{\mathrm{a}, \mathrm{h}, \mathrm{e}, \mathrm{g}}$ \\
\hline $\mathrm{CQ} 25 \mathrm{mg} / \mathrm{kg}$ & $1.43 \pm 0.75^{\mathrm{a}, \mathrm{b}, \mathrm{c}, \mathrm{h}}$ & 95.72 & $27.00 \pm 2.03^{\mathrm{a}, \mathrm{b}, \mathrm{c}, \mathrm{h}, \mathrm{d}, \mathrm{g}}$ \\
\hline
\end{tabular}

Notes: Data are expressed as mean \pm SEM; $[n=6]$. ${ }^{a}$ Compared to neg. control; ${ }^{b}$ Compared to $100 \mathrm{mg} / \mathrm{kg} ;{ }^{\circ} \mathrm{Compared}$ to $200 \mathrm{mg} / \mathrm{kg}$; ${ }^{\mathrm{d}} \mathrm{Compared}$ to $400 \mathrm{mg} / \mathrm{kg}$; ${ }^{\mathrm{e} C o m p a r e d}$ to CQ25mg/kg; ${ }^{f} \mathrm{p}<0.05,{ }^{g} \mathrm{p}<0.01,{ }^{\mathrm{h}} \mathrm{p}<0.001$.

Abbreviations: CON, negative control; CM, methanolic crude extract; $\mathrm{CQ}$, chloroquine. 
Table 4 Mean Percent Parasitemia, Mean Percent Parasitemia Inhibition, and Mean Survival Time of $P$. berghei Infected Mice Treated with Solvent Fractions of $C$. molle Leaves in the 4-Day Suppressive Test

\begin{tabular}{|c|c|c|c|}
\hline Extract/Fraction & $\%$ Parasitemia & \% Parasitemia Inhibition & Mean Survival Time (Days) \\
\hline $\mathrm{CON} I 0 \mathrm{ml} / \mathrm{kg}$ & $37.65 \pm 0.56$ & 0.00 & $5.67 \pm 0.56$ \\
\hline CFI00mg/kg & $17.72 \pm 3.12^{\mathrm{a}, \mathrm{e}, \mathrm{g}}$ & 52.93 & $6.50 \pm 0.67 d 2^{\mathrm{e}, \mathrm{h}}$ \\
\hline CF $200 \mathrm{mg} / \mathrm{kg}$ & $17.2 \pm 2.54^{\mathrm{a}, \mathrm{e}, \mathrm{g}}$ & 54.32 & $8.17 \pm 1.05^{\mathrm{e}, \mathrm{h}}$ \\
\hline $\mathrm{CF} 400 \mathrm{mg} / \mathrm{kg}$ & $12.15 \pm\left. 4.6\right|^{\mathrm{a}, \mathrm{h}}$ & 67.73 & $12.83 \pm 2.75^{\mathrm{a}, \mathrm{b}, \mathrm{g}, \mathrm{e}, \mathrm{h}}$ \\
\hline $\mathrm{HFI00mg/kg}$ & $28.76 \pm 0.74^{\mathrm{e}, \mathrm{h}}$ & 23.61 & $5.83 \pm 0.54^{\mathrm{e}, \mathrm{h}}$ \\
\hline $\mathrm{HF} 200 \mathrm{mg} / \mathrm{kg}$ & $27.25 \pm 2.64^{\mathrm{a}, \mathrm{fe}, \mathrm{h}}$ & 27.62 & $6.50 \pm 0.76^{\mathrm{e}, \mathrm{h}}$ \\
\hline $\mathrm{HF} 400 \mathrm{mg} / \mathrm{kg}$ & $20.72 \pm 2.20^{\mathrm{a}, \mathrm{h}, \mathrm{e}, \mathrm{h}}$ & 44.97 & $8.33 \pm 1.23^{\mathrm{e}, \mathrm{h}}$ \\
\hline $\mathrm{HFI00mg/kg}$ & $26.55 \pm 1.91^{\mathrm{a}, \mathrm{f}, \mathrm{e}, \mathrm{h}}$ & 29.48 & $6.83 \pm 0.70^{\mathrm{e}, \mathrm{h}}$ \\
\hline $\mathrm{HF} 200 \mathrm{mg} / \mathrm{kg}$ & $20.27 \pm I .49^{\mathrm{a}, \mathrm{e}, \mathrm{h}}$ & 46.16 & $8.33 \pm 0.84^{\mathrm{e}, \mathrm{h}}$ \\
\hline $\mathrm{HF} 400 \mathrm{mg} / \mathrm{kg}$ & $18.40 \pm 1.75^{\mathrm{a}, \mathrm{e}, \mathrm{h}}$ & 51.13 & $10.83 \pm 1.78^{\mathrm{a}, \mathrm{g}, \mathrm{e}, \mathrm{h}}$ \\
\hline $\mathrm{CQ} 25 \mathrm{mg} / \mathrm{kg}$ & $0.83 \pm 0.49^{\mathrm{a}, \mathrm{b}, \mathrm{c}, \mathrm{d}, \mathrm{h}}$ & 97.8 & $29.50 \pm 0.34^{\mathrm{a}, \mathrm{b}, \mathrm{c}, \mathrm{d}, \mathrm{h}}$ \\
\hline
\end{tabular}

Notes: Data are expressed as mean \pm SEM; [n $=6$ ]. ${ }^{\mathrm{a} C}$ Compared to neg. control; ${ }^{\mathrm{b}}$ compared to $100 \mathrm{mg} / \mathrm{kg}$; ${ }^{\mathrm{c} C o m p a r e d ~ t o ~} 200 \mathrm{mg} / \mathrm{kg}$; ${ }^{\mathrm{d}} \mathrm{Compared}$ to $400 \mathrm{mg} / \mathrm{kg}$; ${ }^{\mathrm{e}} \mathrm{Compared}$ to CQ25mg/kg: ${ }^{\mathrm{f}} \mathrm{p}<0.05,{ }^{\mathrm{g}} \mathrm{p}<0.01,{ }^{\mathrm{h}} \mathrm{p}<0.001$.

Abbreviations: $\mathrm{CON}$, negative control; $\mathrm{CF}$, chloroform fraction of $C$. molle; HF, hexane fraction of $C$. molle; $A F$, aqueous fraction of $C$. molle; $C Q$, chloroquine.

Table 5 Mean Percent Body Weight Change of $P$. berghei Infected Mice Treated with Methanolic Crude Extract of $C$. molle Leaves in the 4-Day Suppressive Test

\begin{tabular}{|l|l|l|l|}
\hline Extract/Fraction & Body Weight at Day 0 & Body Weight at Day 4 & Percent Change in Body Weight \\
\hline CONIOml/kg & $29.93 \pm 0.49$ & $27.64 \pm 0.35$ & $-8.29 \pm 1.24$ \\
CMI00mg/kg & $27.43 \pm 1.06$ & $26.58 \pm 1.05$ & $-3.24 \pm 0.84$ \\
CM200mg/kg & $27.64 \pm 1.21$ & $25.67 \pm 1.10$ & $-7.8 I \pm 2.74$ \\
CM400mg/kg & $27.46 \pm 0.89$ & $25.84 \pm 1.10$ & $-6.73 \pm 3.28$ \\
CQ25mg/kg & $27.94 \pm 1.48$ & $27.78 \pm 1.42$ & $-0.55 \pm 0.34$ \\
\hline
\end{tabular}

Note: Data are expressed as mean \pm SEM $(n=6)$.

Abbreviations: $\mathrm{CON}$, negative control (solvent $10 \mathrm{~mL} / \mathrm{kg}$ ); $\mathrm{CM}$, crude methanolic extract of $C$. molle leaves.

Table 6 Mean Percent Body Weight Change of P. berghei Infected Mice Treated Solvent Fractions of C. molle Leaves in the 4-Day Suppressive Test

\begin{tabular}{|l|l|l|l|}
\hline Extract/Fraction & Body Weight at Day 0 & Body Weight at Day 4 & Percent Change in Body Weight \\
\hline CONIOml/kg & $29.04 \pm 1.01$ & $27.73 \pm 0.61$ & $-4.62 \pm 1.78$ \\
CFI00mg/kg & $28.08 \pm 0.97$ & $26.45 \pm 0.95$ & $-6.29 \pm 2.24$ \\
CF200mg/kg & $28.38 \pm 0.82$ & $26.80 \pm 0.69$ & $-5.90 \pm 1.19$ \\
CF400mg/kg & $27.44 \pm 1.59$ & $27.25 \pm 1.60$ & $-0.76 \pm 0.64$ \\
$\mathrm{HFI00mg/kg}$ & $27.63 \pm 1.64$ & $26.79 \pm 1.21$ & $-2.86 \pm 2.14$ \\
$\mathrm{HF} 200 \mathrm{mg} / \mathrm{kg}$ & $26.53 \pm 1.59$ & $26.27 \pm 1.96$ & $-1.95 \pm 3.70$ \\
$\mathrm{HF} 400 \mathrm{mg} / \mathrm{kg}$ & $29.79 \pm 0.86$ & $29.24 \pm 0.60$ & $-1.79 \pm 1.04$ \\
AFI00mg/kg & $26.97 \pm 1.22$ & $26.78 \pm 1.31$ & $-0.87 \pm 1.35$ \\
AF200mg/kg & $26.72 \pm 1.44$ & $26.45 \pm 1.59$ & $-1.23 \pm 1.15$ \\
AF400mg/kg & $26.41 \pm 0.86$ & $26.20 \pm 0.79$ & $-0.77 \pm 0.87$ \\
CQ25mg/kg & $26.20 \pm 1.1 \mathrm{I}$ & $27.55 \pm 1.28$ & $+4.78 \pm 1.20^{\mathrm{a}, \mathrm{b}}$ \\
\hline
\end{tabular}

Notes: Data are expressed as mean \pm SEM; $[n=6]$. ${ }^{a}$ Compared to negative control; ${ }^{b}<<0.00 I$.

Abbreviations: $\mathrm{CON}$, negative control (solvent $10 \mathrm{~mL} / \mathrm{kg}$ ); $\mathrm{CF}$, chloroform fraction of $C$. molle; HF, hexane fraction of $C$. molle; $A F$, aqueous fraction of $C$. molle; $C Q$, chloroquine.

P. berghei infected mice treated with methanolic crude extract of C. molle leaves at $100,200,400 \mathrm{mg} /$ $\mathrm{kg} / \mathrm{day} \quad$ showed $\quad 7.83 \pm 0.40 \quad(\mathrm{P}=0.997), \quad 9.50 \pm 0.72$
$(\mathrm{P}=0.248), 12.17 \pm 1.01(\mathrm{P}<0.001)$ days of mean survival time in curative test, respectively. Chloroform fraction of C. molle leaf at $100,200,400 \mathrm{mg} / \mathrm{kg} /$ day and 
Table 7 Mean Percent Change of Body Temperature of $P$. berghei Infected Mice Treated with Methanolic Crude Extract of $C$. molle Leaves in the 4-Day Suppressive Test

\begin{tabular}{|l|l|l|l|}
\hline Extract/Fraction & Body Temp at Day 0 & Body Temp at Day 4 & Percent Change in Body Temperature \\
\hline CON10ml/kg & $36.38 \pm 0.16$ & $35.03 \pm 0.18$ & $-2.67 \pm 0.55$ \\
CM100mg/kg & $36.43 \pm 0.10$ & $35.61 \pm 0.16$ & $-0.88 \pm 1.01$ \\
CM200mg/kg & $36.62 \pm 0.17$ & $36.10 \pm 0.16$ & $-0.78 \pm 0.56^{\mathrm{a}, \mathrm{b}}$ \\
CM400mg/kg & $36.08 \pm 0.23$ & $35.87 \pm 0.16$ & $-0.75 \pm 0.86$ \\
CQ25mg/kg & $36.32 \pm 0.15$ & $36.27 \pm 0.13$ & $-0.04 \pm 0.18$ \\
\hline
\end{tabular}

Notes: Data are expressed as mean \pm SEM $[n=6]$. ${ }^{a}$ Compared to neg. control: ${ }^{b} p<0.01$.

Abbreviations: $\mathrm{CON}$, control (solvent $10 \mathrm{~mL} / \mathrm{kg}$ ); $\mathrm{CM}$, crude methanolic extract; $\mathrm{CQ}$, chloroquine.

Table 8 Mean Percent Change of Body Temperature of $P$. berghei Infected Mice Treated with Solvent Fractions of $C$. molle Leaves in the 4-Day Suppressive Test

\begin{tabular}{|l|l|l|l|}
\hline Extract/Fraction & Body Temp at Day 0 & Body Temp at Day 4 & Percent Change in Body Temperature \\
\hline CONIOml/kg & $36.17 \pm 0.22$ & $34.70 \pm 0.17$ & $-4.25 \pm 0.83$ \\
CF100mg/kg & $37.03 \pm 0.30$ & $35.94 \pm 0.29$ & $-3.07 \pm 0.95^{\mathrm{b}, \mathrm{c}}$ \\
CF200mg/kg & $36.97 \pm 0.30$ & $35.92 \pm 0.21$ & $-2.91 \pm 0.51^{\mathrm{b}, \mathrm{c}}$ \\
CF400mg/kg & $36.93 \pm 0.28$ & $36.57 \pm 0.25$ & $-1.00 \pm 0.23$ \\
$\mathrm{HFI00mg/kg}$ & $36.27 \pm 0.25$ & $34.97 \pm 0.33$ & $-3.75 \pm 0.99^{\mathrm{b}, \mathrm{c}}$ \\
$\mathrm{HF} 200 \mathrm{mg} / \mathrm{kg}$ & $36.82 \pm 0.20$ & $36.22 \pm 0.30$ & $-1.67 \pm 0.46^{\mathrm{b}, \mathrm{c}}$ \\
$\mathrm{HF} 400 \mathrm{mg} / \mathrm{kg}$ & $36.42 \pm 0.13$ & $35.78 \pm 0.27$ & $-1.81 \pm 1.05^{\mathrm{a}, \mathrm{c}}$ \\
AFI00mg/kg & $36.25 \pm 0.12$ & $35.47 \pm 0.53$ & $-2.33 \pm 1.60$ \\
AF200mg/kg & $36.38 \pm 0.16$ & $35.40 \pm 0.28$ & $-2.82 \pm 1.02$ \\
AF400mg/kg & $36.17 \pm 0.06$ & $36.10 \pm 0.12$ & $-0.19 \pm 0.30^{\mathrm{a}, \mathrm{c}}$ \\
CQ25mg/kg & $36.38 \pm 0.05$ & $36.28 \pm 0.06$ & $-0.28 \pm 0.17^{\mathrm{a}, \mathrm{c}}$ \\
\hline
\end{tabular}

Notes: Data are expressed as mean \pm SEM $(n=6)$. ${ }^{a}$ Compared to neg. control; ${ }^{b}$ compared to $\mathrm{CQ} 25 \mathrm{mg} / \mathrm{kg}:{ }^{\mathrm{c}} \mathrm{p}<0.0 \mathrm{I}$.

Abbreviations: $\mathrm{CON}$, control (solvent $10 \mathrm{~mL} / \mathrm{kg}$ ); $\mathrm{CF}$, chloroform fraction of $C$. molle; HF, hexane fraction of $C$. molle; $\mathrm{AF}$, aqueous fraction of $C$. molle; $\mathrm{CQ}$, chloroquine.

Table 9 Mean Percent Packed Cell Volume and Mean Percent Packed Cell Volume Change of P. berghei Infected Mice Treated with Methanolic Crude Extract of C. molle Leaf in the 4-Day Suppressive Test

\begin{tabular}{|l|l|l|l|}
\hline Extract/Fraction & Packed Cell Volume at Day 0 & Packed Cell Volume at Day 4 & Percent Change in Packed Cell Volume \\
\hline CONIOml/kg & $50.33 \pm 2.50$ & $46.40 \pm 2.06$ & $-5.08 \pm 0.71$ \\
CMI00mg/kg & $47.67 \pm 0.67$ & $45.50 \pm 1.32$ & $-3.97 \pm 1.45$ \\
CM200mg/kg & $49.50 \pm 1.48$ & $48.25 \pm 2.02$ & $-2.53 \pm 0.97$ \\
CM400mg/kg & $46.17 \pm 1.94$ & $45.60 \pm 2.29$ & $-1.75 \pm 0.82$ \\
CQ25mg/kg & $48.17 \pm 1.89$ & $47.33 \pm 1.86$ & $-1.77 \pm 0.36$ \\
\hline
\end{tabular}

Notes: Data are expressed as mean \pm SEM; $n=6$.

Abbreviations: $\mathrm{CON}$, control (solvent $10 \mathrm{~mL} / \mathrm{kg}$ ); $\mathrm{CM}$, crude methanolic extract of $C$. molle; $\mathrm{CQ}$, chloroquine.

Chloroquine base at $25 \mathrm{mg} / \mathrm{kg} /$ day showed $8.17 \pm 0.48$ $(\mathrm{P}=0.921), \quad 10.33 \pm 0.80 \quad(\mathrm{P}=0.014), \quad 13.17 \pm 0.48$ $(\mathrm{P}<0001) 28.83 \pm 0.65(\mathrm{P}<0.001)$ days of mean survival time in curative test, respectively. Crude hydromethanolic extract and chloroform fraction at $400 \mathrm{mg} / \mathrm{kg}$ and Chloroquine base at $25 \mathrm{mg} / \mathrm{kg} /$ day showed highly significant $(\mathrm{P}<0.001)$ in survival days compared to negative controls $(7.50 \pm 0.34)$ (see Table 11).
Effect of Methanolic Crude Extract and Chloroform Fraction of $C$. molle Leaves on Body Weight of $P$. berghei Infected Mice

Plasmodium berghei infected mice treated with methanolic crude extract of C. molle leaves at $100 \mathrm{mg} / \mathrm{kg} / \mathrm{day}, 200 \mathrm{mg} / \mathrm{kg} /$ day, and $400 \mathrm{mg} / \mathrm{kg}$ gain $2.41 \pm 1.91 \%$ ( $\mathrm{p}=0.011), 0.88 \pm 2.14 \%$ ( $\mathrm{p}=0.128), 4.38 \pm 1.01 \%(\mathrm{p}=697)$, chloroform fraction of $C$. 
Table 10 Mean Percent Packed Cell Volume and Mean Percent Packed Cell Volume Change of $P$. berghei Infected Mice Treated with Solvent Fractions of $C$. molle Leaves in the 4-Day Suppressive Test

\begin{tabular}{|c|c|c|c|}
\hline Extract/Fraction & Packed Cell Volume at Day 0 & Packed Cell Volume at Day 4 & Percent Change in Packed Cell Volume \\
\hline $\mathrm{CON} 10 \mathrm{ml} / \mathrm{kg}$ & $54.67 \pm 0.99$ & $50.75 \pm 1.03$ & $-8.36 \pm 0.91$ \\
\hline CFIOOmg/kg & $42.17 \pm 1.78$ & $39.10 \pm 2.35$ & $-12.24 \pm 8.12$ \\
\hline $\mathrm{CF} 200 \mathrm{mg} / \mathrm{kg}$ & $45.50 \pm 2.09$ & $46.00 \pm 2.48$ & $-1.7 \mid \pm 0.58$ \\
\hline CF400mg/kg & $47.50 \pm 1.77$ & $48.75 \pm 2.39$ & $3.07 \pm 2.06$ \\
\hline $\mathrm{HFI00mg/kg}$ & $53.50 \pm 1.34$ & $51.00 \pm 1.58$ & $-4.72 \pm 0.79^{\mathrm{d}, \mathrm{e}}$ \\
\hline $\mathrm{HF} 200 \mathrm{mg} / \mathrm{kg}$ & $52.33 \pm 1.96$ & $50.17 \pm 2.09$ & $-4.46 \pm 1.35$ \\
\hline $\mathrm{HF} 400 \mathrm{mg} / \mathrm{kg}$ & $50.00 \pm 3.31$ & $50.60 \pm 3.50$ & $-3.52 \pm 1.48$ \\
\hline $\mathrm{AFI} 00 \mathrm{mg} / \mathrm{kg}$ & $52.00 \pm 2.18$ & $50.50 \pm 1.44$ & $-5.42 \pm 1.18^{\mathrm{d}, \mathrm{e}}$ \\
\hline AF200mg/kg & $50.50 \pm 1.95$ & $48.50 \pm 2.31$ & $-4.40 \pm 1.43^{\mathrm{d}, \mathrm{e}}$ \\
\hline $\mathrm{AF} 400 \mathrm{mg} / \mathrm{kg}$ & $44.83 \pm 2.61$ & $45.20 \pm 2.96$ & $-1.86 \pm 0.48^{\mathrm{a}, \mathrm{f}}$ \\
\hline $\mathrm{CQ} 25 \mathrm{mg} / \mathrm{kg}$ & $49.00 \pm 2.68$ & $48.83 \pm 2.63$ & $-0.32 \pm 0.32^{\mathrm{a}, \mathrm{g}, \mathrm{b}, \mathrm{c}, \mathrm{f}}$ \\
\hline
\end{tabular}

Notes: Data are expressed as mean \pm SEM; $n=6$. ${ }^{a}$ Compared to neg. control; ${ }^{b}$ Compared to $100 \mathrm{mg} / \mathrm{kg}$; ${ }^{\mathrm{c} C o m p a r e d}$ to $200 \mathrm{mg} / \mathrm{kg}$; ${ }^{\mathrm{d}}$ Compared to CQ25mg/kg: ${ }^{\mathrm{e}} \mathrm{p}<0.05,{ }^{\mathrm{f}} \mathrm{p}<0.01$, ${ }^{\mathrm{g} p}<0.001$.

Abbreviations: $\mathrm{CON}$, control (solvent $10 \mathrm{~mL} / \mathrm{kg}$ ); $\mathrm{CF}$, chloroform fraction of $C$. molle; $\mathrm{HF}$, hexane fraction of $C$.; $\mathrm{AF}$, aqueous fraction of $C$. molle; $\mathrm{CQ}$, chloroquine.

Table I I Percent Parasitaemia and Percent Parasitemia Inhibition and Survival Date of $P$. berghei Infected Mice Treated with Crude Methanolic Extract and Chloroform Fraction of C. molle Leaves in Curative Test

\begin{tabular}{|c|c|c|c|c|c|c|c|}
\hline \multirow{2}{*}{$\begin{array}{l}\text { Extract/ } \\
\text { Fraction }\end{array}$} & \multirow{2}{*}{$\begin{array}{l}\text { \% Para Day } \\
3\end{array}$} & \multirow{2}{*}{$\begin{array}{l}\% \text { Para } \\
\text { Day } 4\end{array}$} & \multirow{2}{*}{$\begin{array}{l}\text { \% Para Day } \\
5\end{array}$} & \multirow{2}{*}{$\begin{array}{l}\text { \% Para Day } \\
6\end{array}$} & \multicolumn{2}{|l|}{ Day 7} & \multirow{2}{*}{$\begin{array}{l}\text { Mean Survival Time (in } \\
\text { Days) }\end{array}$} \\
\hline & & & & & \% Parasitemia & $\begin{array}{l}\text { \% Parasitemia } \\
\text { Inhibition }\end{array}$ & \\
\hline CONIOml/kg & $22.73 \pm 0.84$ & $24.95 \pm 0.92$ & $27.55 \pm 0.73$ & $32.68 \pm 0.29$ & $38.76 \pm 0.82$ & 0.00 & $7.50 \pm 0.34$ \\
\hline CM100mg/kg & $24.77 \pm 0.72$ & $24.58 \pm 0.73$ & $23.72 \pm 0.65$ & $22.77 \pm 0.67$ & $21.98 \pm 0.76^{\mathrm{a}, \mathrm{c}, \mathrm{d}, \mathrm{e}, \mathrm{h}}$ & 43.29 & $7.83 \pm 0.40^{\mathrm{d}, \mathrm{h}, \mathrm{e}, \mathrm{h}}$ \\
\hline CM200mg/kg & $22.33 \pm 0.60$ & $23.02 \pm 0.48$ & $20.48 \pm 0.65$ & $17.37 \pm 0.79$ & $14.35 \pm 1.01^{\mathrm{a}, \mathrm{b}, \mathrm{e}, \mathrm{h}}$ & 62.98 & $9.50 \pm 0.72^{\mathrm{e}, \mathrm{h}}$ \\
\hline CM400mg/kg & $22.57 \pm 0.48$ & $23.32 \pm 0.50$ & $17.77 \pm 0.49$ & $14.03 \pm 0.54$ & $12.22 \pm 0.49^{\mathrm{a}, \mathrm{b}, \mathrm{e}, \mathrm{h}}$ & 68.48 & $12.17 \pm\left. 1.0\right|^{\mathrm{a}, \mathrm{h}, \mathrm{b}, \mathrm{h}, \mathrm{e}, \mathrm{h}}$ \\
\hline CFI00mg/kg & $25.17 \pm 0.33$ & $25.08 \pm 0.46$ & $23.92 \pm 0.74$ & $22.48 \pm 0.58$ & $22.18 \pm 0.38^{\mathrm{a}, \mathrm{d}, \mathrm{e}, \mathrm{h}, \mathrm{c}, \mathrm{g}}$ & 42.78 & $8.17 \pm 0.48^{\mathrm{d}, \mathrm{e}, \mathrm{h}}$ \\
\hline CF200mg $/ \mathrm{kg}$ & $23.50 \pm 0.89$ & $24.07 \pm 0.59$ & $21.95 \pm 1.00$ & $19.15 \pm 1.13$ & $17.33 \pm 1.25^{\mathrm{a}, \mathrm{e}, \mathrm{h}, \mathrm{b}, \mathrm{d}, \mathrm{g}}$ & 55.29 & $10.33 \pm 0.80^{\mathrm{a}, \mathrm{d}, \mathrm{h}, \mathrm{e}, \mathrm{h}}$ \\
\hline CF400mg $/ \mathrm{kg}$ & $24.75 \pm 1.21$ & $24.43 \pm 0.82$ & $22.12 \pm 0.89$ & $17.75 \pm 0.65$ & $11.93 \pm 0.96^{\text {a,b,e, h,c, }, g}$ & 69.22 & $13.17 \pm 0.48^{\mathrm{a}, \mathrm{b}, \mathrm{e}, \mathrm{h}, \mathrm{c}, \mathrm{f}}$ \\
\hline CQ25mg & $23.17 \pm 0.84$ & $17.53 \pm 0.97$ & $8.07 \pm 1.92$ & $2.37 \pm 0.90$ & $0.37 \pm 0.27^{\mathrm{a}, \mathrm{b}, \mathrm{c}, \mathrm{d}, \mathrm{h}}$ & 99.05 & $28.83 \pm 0.65^{\mathrm{a}, \mathrm{b}, \mathrm{c}, \mathrm{d}, \mathrm{h}}$ \\
\hline
\end{tabular}

Notes: Data are expressed as mean \pm SEM; $\left[\mathrm{n}=6\right.$ 6 ${ }^{\mathrm{a}}$ Compared to negative control; ${ }^{\mathrm{b}}$ Compared to $100 \mathrm{mg} / \mathrm{kg} ;{ }^{\mathrm{C}}$ Compared to $200 \mathrm{mg} / \mathrm{kg}$; ${ }^{\mathrm{d}} \mathrm{Compared}$ to $400 \mathrm{mg} / \mathrm{kg}$; ${ }^{e}$ Compared to CQ25mg/kg: ${ }^{f} p<0.05,{ }^{g} p<0.01,{ }^{h} p<0.001$.

Abbreviations: $\mathrm{CON}$, control (solvent $10 \mathrm{~mL} / \mathrm{kg}$ ); $\mathrm{CM}$, crude methanolic extract; $\mathrm{CF}$, chloroform fraction of $\mathrm{C}$. molle; $\mathrm{CQ}$, chloroquine.

molle leaves at 100,200 , and $400 \mathrm{mg} / \mathrm{kg}$ loss $8.48 \pm 2.04 \%$ $(\mathrm{p}=0.473), 7.45 \pm 1.52 \% \quad(\mathrm{p}=0.592), 11.25 \pm 3.00 \%(\mathrm{P}=0.215)$ and chloroquine base at $25 \mathrm{mg} / \mathrm{kg} /$ day gain $2.42 \pm 0.93 \%(\mathrm{P}=$ 0.315 ) of weight and mice treated with solvent $10 \mathrm{~mL} / \mathrm{kg}$ loss $8.18 \pm 3.62 \%$ of weight, respectively, in curative test (See Figure 3).

\section{Effect of Methanolic Crude Extract and}

\section{Chloroform Fraction of $C$. molle Leaves on} Body Temperature of $P$. berghei Infected Mice Plasmodium berghei infected mice treated with methanolic crude extract of C. molle leaves at $100 \mathrm{mg} / \mathrm{kg} / \mathrm{day}, 200 \mathrm{mg} /$ $\mathrm{kg} /$ day and $400 \mathrm{mg} / \mathrm{kg}$ decrease $0.95 \pm 1.36 \%(\mathrm{p}=0.673)$, $0.73 \pm 1.05 \% \quad(\mathrm{p}=0.875) \quad$ increase, $1.01 \pm 1.05 \% \quad(\mathrm{p}=958)$ increase, chloroform fraction of $C$. molle leaves at $100 \mathrm{mg} / \mathrm{kg} / \mathrm{day}, \quad 200 \mathrm{mg} / \mathrm{kg} /$ day and $400 \mathrm{mg} / \mathrm{kg}$ decrease
$2.47 \pm 0.65 \% \quad(\mathrm{p}=0.108), 1.14 \pm 0.92 \% \quad(\mathrm{p}=0.982)$ increase, $0.78 \pm 1.03 \%(\mathrm{P}=0.945)$ increase and chloroquine base at $25 \mathrm{mg} / \mathrm{kg} /$ day $4.86 \pm 1.48 \%(\mathrm{P}=0.538)$ increase and mice treated with solvent $10 \mathrm{~mL} / \mathrm{kg}$ increase $2.10 \pm 1.88 \%$ of body temperature, respectively, in curative test (See Figure 4).

\section{Effect of Methanolic Crude Extract and Chloroform Fraction of $C$. molle Leaves on Packed Cell Volume of $P$. berghei Infected Mice}

Plasmodium berghei infected mice treated with methanolic crude extract of $C$. molle leaves at 100,200, and $400 \mathrm{mg} / \mathrm{kg}$ decrease $0.95 \pm 1.36 \% \quad(\mathrm{p}=0.673), 0.73 \pm 1.05 \% \quad(\mathrm{p}=0.875)$ increase, $1.01 \pm 1.05 \%(\mathrm{p}=958)$ increase, chloroform fraction of C. molle leaves at 100,200 , and $400 \mathrm{mg} / \mathrm{kg}$ 


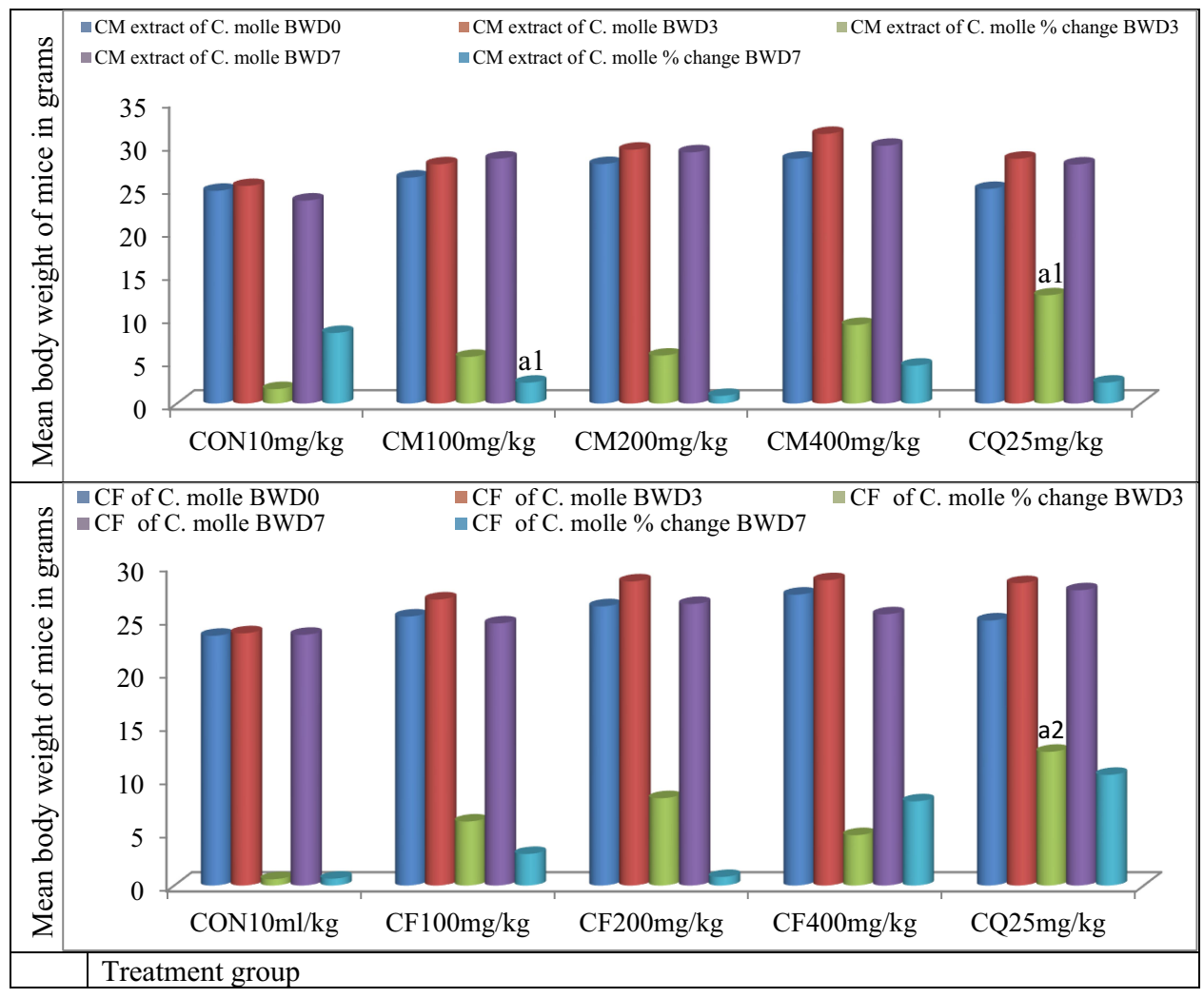

Figure 3 Effect of crude methanolic extract and chloroform fraction of $C$. molle on body weight of $P$. berghei infected mice in a curative test. [N=6]. Compared to negative control: ${ }_{\mathrm{al}}^{\mathrm{p}}<0.05,{ }^{\mathrm{a} 2} \mathrm{p}<0.01$.

Abbreviations:, BWD0, body weight day zero; BWD7, body weight day seven; CON, negative control (solvent $10 \mathrm{~mL} / \mathrm{kg}$ ); CM, crude methanolic extract; CF, chloroform fraction; $\mathrm{CQ}$, chloroquine.

decrease $2.47 \pm 0.65 \% \quad(p=0.108), 1.14 \pm 0.92 \% \quad(p=0.982)$ increase, $0.78 \pm 1.03 \%(\mathrm{P}=0.945)$ increase, and chloroquine base at $25 \mathrm{mg} / \mathrm{kg} /$ day $4.86 \pm 1.48 \%(\mathrm{P}=0.538)$ increase and mice treated with solvent $10 \mathrm{~mL} / \mathrm{kg}$ increase $2.10 \pm 1.88 \%$ of packed cell volume, respectively, in curative test (See Figure 5).

Antimalarial repository test of methanolic crude extract of $C$. molle leaves and chloroquine base against $P$. berghei infected mice resulted in reduced parasite load as compared to their respective negative control group. Methanolic crude extract of $C$. molle leaves at 100, 200, and $400 \mathrm{mg} / \mathrm{kg} / \mathrm{day}$, chloroform fraction of C. molle at 100 , 200 , and $400 \mathrm{mg} / \mathrm{kg}$ and Chloroquine base at $25 \mathrm{mg} / \mathrm{kg} /$ day showed 51.00, 62.65, 76.20, 46.57, 50.86, 71.96, and $99.20 \%$ parasitemia inhibition, respectively, and also the results were highly significant $(\mathrm{P}<0.001)$ compared to the negative control group at day-7 (See Table 12).

Methanolic crude extract of $C$. molle leaves at 100 , $200,400 \mathrm{mg} / \mathrm{kg} / \mathrm{day}$, chloroform fraction of $C$. molle leaves at 100, 200 and $400 \mathrm{mg} / \mathrm{kg}$ and chloroquine base at $25 \mathrm{mg} / \mathrm{kg}$ in prophylactic test showed $7.50 \pm 0.99$
$(\mathrm{P}=0.999), \quad 10.00 \pm 2.31 \quad(\mathrm{P}=0.816), \quad 17.67 \pm 3.05$ $(\mathrm{P}=0.002), \quad 10.17 \pm 1.74 \quad(\mathrm{P}=0.783), \quad 11.33 \pm 2.16$ $(\mathrm{P}=0.516), \quad 17.50 \pm 2.19 \quad(\mathrm{P}=0.003) \quad$ and $\quad 29.00 \pm 0.63$ $(\mathrm{P}<0.001)$ days of mean survival time in seven-day prophylactic test, respectively. Chloroquine base at $25 \mathrm{mg} / \mathrm{kg} /$ day showed highly significant $(\mathrm{P}<0.001)$ in survival days compared to negative controls $6.00 \pm 0.97$ (See Table 12).

\section{Effect of Methanolic Crude Extract and Chloroform Fraction of $C$. molle Leaves on Body Weight of $P$. berghei Infected Mice in Prophylactic Test}

Plasmodium berghei infected mice treated with methanolic crude extract of $C$. molle leaves at 100, 200, and $400 \mathrm{mg} / \mathrm{kg}$ gain $2.62 \pm 6.42 \% \quad(\mathrm{p}=0.679), \quad 6.03 \pm 3.46 \%$ $(p=0.999), 1.60 \pm 2.18 \% \quad(p=979)$. Chloroform fraction of $C$. molle leaves at 100, 200, and $400 \mathrm{mg} / \mathrm{kg}$ loss $9.25 \pm 6.18 \% \quad(p=0.197), \quad 0.36 \pm 0.76 \% \quad(p=1.000), \quad 0.90$ $\pm 0.67 \% \quad(\mathrm{P}=1.000)$ and chloroquine base at $25 \mathrm{mg} / \mathrm{kg} /$ 


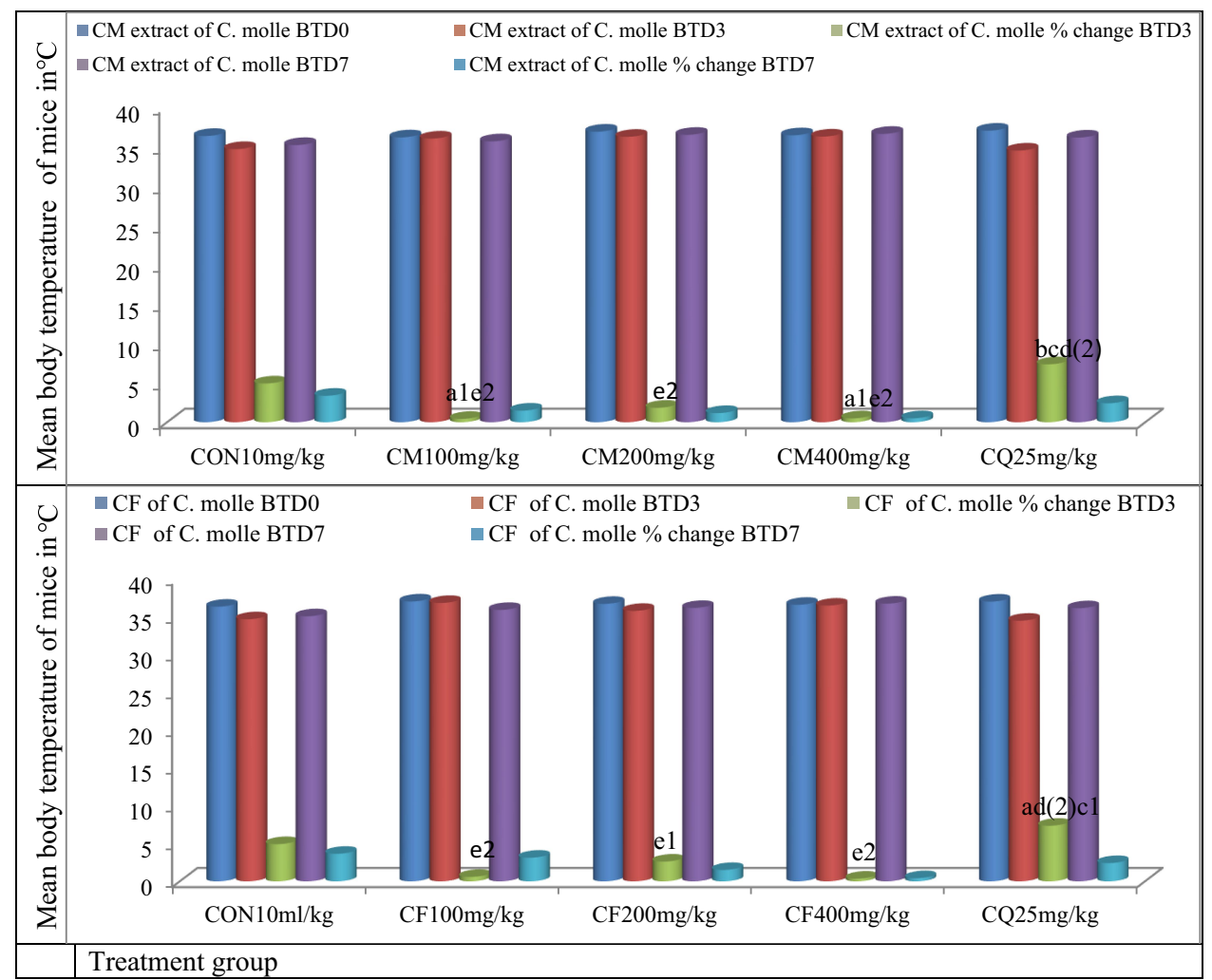

Figure 4 Effect of crude methanolic extract and chloroform fraction of $C$. molle on body temperature of $P$. berghei infected mice in a curative test. [N $=6$ ]. Compared to negative control: al ${ }^{\mathrm{p}}<0.05,{ }^{\mathrm{a} 2} \mathrm{p}<0.01$, compared to $100 \mathrm{mg} / \mathrm{kg}$ : ${ }^{\mathrm{b} 2} \mathrm{p}<0.0 \mathrm{l}$, compared to $200 \mathrm{mk} / \mathrm{kg}$ : ${ }^{\mathrm{cl}} \mathrm{p}<0.05$, ${ }^{2} \mathrm{p}<0.01$, compared to $400 \mathrm{mg} / \mathrm{kg}$ : ${ }^{\mathrm{d} 2} \mathrm{p}<0.01$, compared to $\mathrm{CQ} 10 \mathrm{mg} / \mathrm{kg}$ : ${ }^{\mathrm{el}} \mathrm{p}<0.05,{ }^{\mathrm{e} 2} \mathrm{p}<0.01$.

Abbreviations: BTD0, body temperature at day zero; BTD7, body temperature at day seven; CON, negative control (solvent $10 \mathrm{~mL} / \mathrm{kg}$ ); CM, crude hydromethanolic extract; CF, chloroform fraction of CM; CQ, chloroquine.

day gain $2.27 \pm 2.10 \%(\mathrm{P}=0.991)$ of weight and mice treated with solvent $10 \mathrm{~mL} / \mathrm{kg}$ loss $4.76 \pm 3.93 \%$ of weight, respectively, in prophylactic test (See Figure 6).

\section{Effect of Methanolic Crude Extract and Chloroform Fraction of $C$. molle Leaves on Body Temperature of $P$. berghei Infected Mice}

Plasmodium berghei infected mice treated with methanolic crude extract of $C$. molle leaves at 100, 200, and $400 \mathrm{mg} / \mathrm{kg}$ decrease $0.55 \pm 0.93 \%(\mathrm{p}=0.045), 0.81 \pm 0.77 \%$ $(\mathrm{p}=0.067)$ increase, $1.07 \pm 1.18 \% \quad(\mathrm{p}=099)$ increase, chloroform fraction of C. molle leaves at 100, 200, and $400 \mathrm{mg} / \mathrm{kg}$ decrease $0.20 \pm 0.29 \% \quad(\mathrm{p}=0.888), 0.08$ $\pm 0.48 \% \quad(\mathrm{p}=0.598) \quad$ increase, $\quad 0.99 \pm 0.48 \% \quad(\mathrm{P}=0.967)$ increase and chloroquine base at $25 \mathrm{mg} / \mathrm{kg} /$ day 0.53 $\pm 0.88 \%(\mathrm{P}=0.008)$ increase and mice treated with solvent $10 \mathrm{~mL} / \mathrm{kg}$ increase $4.71 \pm 1.12 \%$ of vital sign, respectively, in prophylactic test (See Figure 7).

\section{Effect of Methanolic Crude Extract and Chloroform Fraction of $C$. molle Leaves on Packed Cell Volume of $P$. berghei Infected Mice}

Plasmodium berghei infected mice treated with methanolic crude extract of $C$. molle leaves at 100, 200, and $400 \mathrm{mg} / \mathrm{kg}$ decrease $7.06 \pm 2.44 \%(\mathrm{p}=0.673), 2.69 \pm 2.01 \%$ $(\mathrm{p}=0.875) \quad$ increase, $\quad 5.48 \pm 3.60 \% \quad(\mathrm{p}=958) \quad$ increase chloroquine base at $25 \mathrm{mg} / \mathrm{kg} /$ day $0.92 \pm 1.06 \% \quad(\mathrm{P}=$ 0.538 ) increase and mice treated with solvent $10 \mathrm{~mL} /$ $\mathrm{kg}$ increase $12.68 \pm 0.75 \%$ of packed cell volume, respectively, in prophylactic test. Chloroform fraction of C. molle leaves at 100, 200, and $400 \mathrm{mg} / \mathrm{kg}$ decrease $2.25 \pm 0.48 \% \quad(p=0.062), \quad 5.00 \pm 1.58 \% \quad(p=0.201)$ increase, $1.20 \pm 0.66 \%(\mathrm{P}=0.052)$ increase and chloroquine base at $25 \mathrm{mg} / \mathrm{kg} /$ day $0.50 \pm 0.56 \% \quad(\mathrm{P}=0.138)$ increase and mice treated with solvent $10 \mathrm{~mL} / \mathrm{kg}$ increase $13.17 \pm 7.58 \%$ of packed cell volume, respectively, in prophylactic test (See Figure 8). 


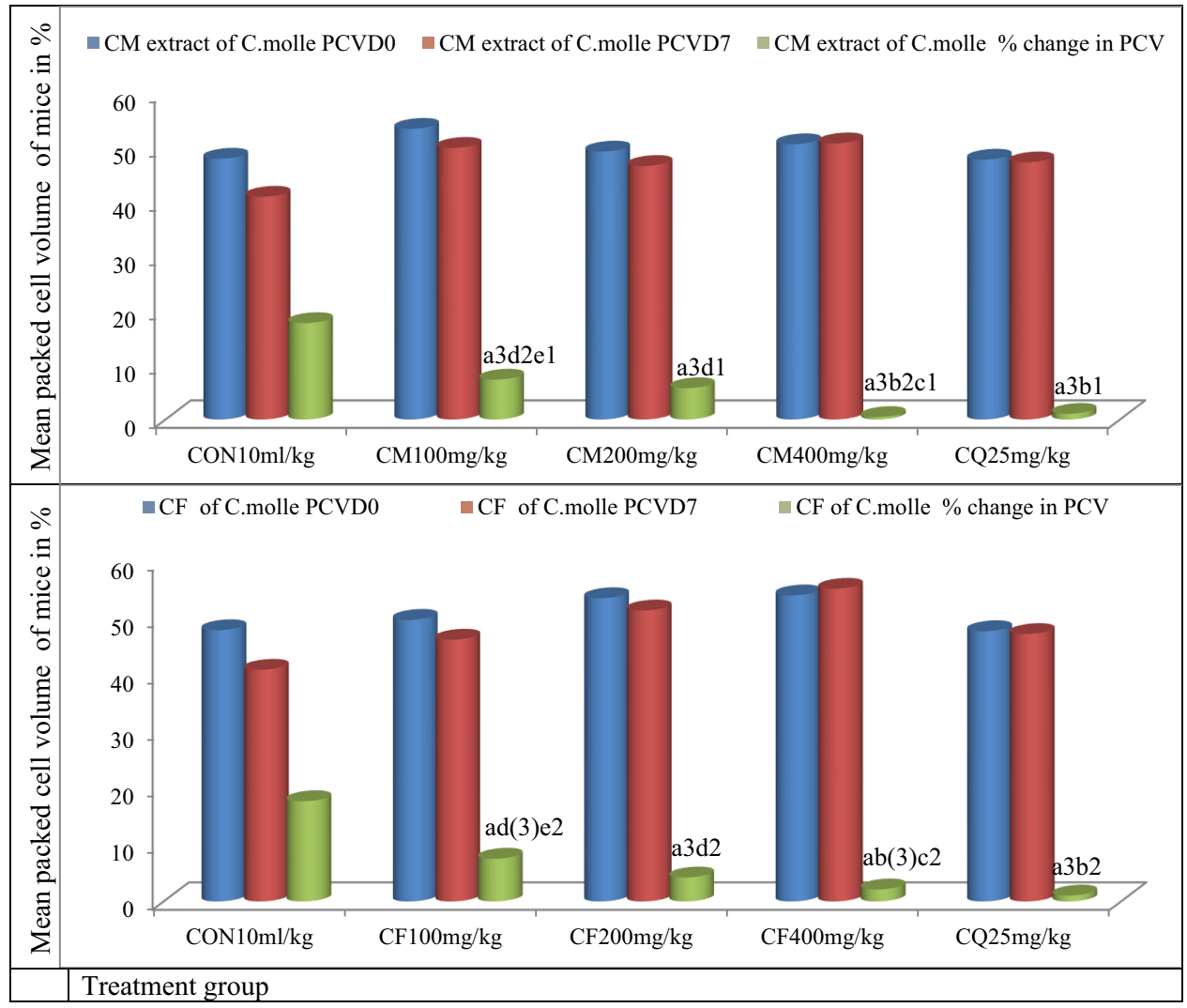

Figure 5 Effect of crude methanolic extract and chloroform fraction of $C$. molle on packed cell volume of $P$. berghei infected mice in a curative test. [N $=6$ ]. Compared to negative control: ${ }^{\mathrm{a} 3} \mathrm{p}<0.00 \mathrm{I}$, compared to $100 \mathrm{mg} / \mathrm{kg}$ : ${ }^{\mathrm{bl}} \mathrm{p}<0.05,{ }^{\mathrm{b} 2} \mathrm{p}<0.0 \mathrm{I},{ }^{\mathrm{b} 3} \mathrm{p}<0.00 \mathrm{I}$, compared to $200 \mathrm{mk} / \mathrm{kg}$ : ${ }^{\mathrm{cl}} \mathrm{p}<0.05$, ${ }^{\mathrm{c} 2} \mathrm{p}<0.0 \mathrm{l}, \mathrm{compared}$ to $400 \mathrm{mg} / \mathrm{kg}$ : ${ }^{\mathrm{dl}} \mathrm{p}<0.05$, ${ }^{\mathrm{d} 2} \mathrm{p}<0.0 \mathrm{I}$, ${ }^{\mathrm{d} 3} \mathrm{p}<0.001$, compared to $\mathrm{CQ} 10 \mathrm{mg} / \mathrm{kg}$ : ${ }^{\mathrm{el}} \mathrm{p}<0.05,{ }^{\mathrm{e} 2} \mathrm{p}<0.01$.

Abbreviations: PCV0, packed cell volume at day zero; PCV7, packed cell volume at day zero; CON, negative control (solvent $10 \mathrm{~mL} / \mathrm{kg}$ ); CM, crude hydromethanolic extract; CF, chloroform fraction of CM; CQ, chloroquine.

\section{Discussion}

Currently, Malaria management causes an enormous threat due to resistance of plasmodium species to available drugs. ${ }^{7}$ There is a requirement to possess a replacement and effective agent. Therefore, we assessed antimalarial activity of methanolic crude extract and solvent fractions of $C$. molle leaves in P. berghei infected mice. In Ethiopia, different parts of $C$. molle are wont to treat parasitic, protozoan and other infectious diseases. ${ }^{16}$ From the promising results of the in vitro cell culture of $P$. falciparum $\mathrm{K} 1$ on leaves, root bark, and stem bark of C. molle $e^{19-21}$ and traditional antimalarial use of $C$. molle, the in vivo

Table 12 Mean Percent Parasitemia and Mean Percent Parasitemia Inhibition and Mean Survival Time of P. berghei Infected Mice Treated with Methanolic Crude Extract and Chloroform Fraction of C. molle Leaves in Prophylactic Test

\begin{tabular}{|c|c|c|c|}
\hline Extract/fraction & Percent Parasitemia & Percent Parasitemia Inhibition & Mean Survival Time \\
\hline 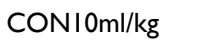 & $24.90 \pm 2.16$ & 0.00 & $6.00 \pm 0.97$ \\
\hline $\mathrm{CM} 100 \mathrm{mg} / \mathrm{kg}$ & $12.20 \pm\left. 0.4\right|^{\mathrm{a}, \mathrm{e}, \mathrm{h}, \mathrm{d}, \mathrm{g}}$ & 51.00 & $7.50 \pm 0.99^{\mathrm{d}, \mathrm{f}, \mathrm{e}, \mathrm{h}}$ \\
\hline $\mathrm{CM} 200 \mathrm{mg} / \mathrm{kg}$ & $9.30 \pm 0.56^{\mathrm{a}, \mathrm{e}, \mathrm{h}}$ & 62.65 & $10.00 \pm\left. 2.3\right|^{\mathrm{e}, \mathrm{h}}$ \\
\hline $\mathrm{CM} 400 \mathrm{mg} / \mathrm{kg}$ & $5.93 \pm 0.49^{a, 3, b, e, g}$ & 76.20 & $17.67 \pm 3.05^{\mathrm{a}, \mathrm{e}, \mathrm{h}, \mathrm{b}, \mathrm{f}}$ \\
\hline $\mathrm{CFI} 100 \mathrm{mg} / \mathrm{kg}$ & $10.58 \pm 0.48^{\mathrm{a}, \mathrm{d}, \mathrm{e}, \mathrm{h}}$ & 46.57 & $10.17 \pm 1.74^{\mathrm{e}, \mathrm{h}}$ \\
\hline CF200mg/kg & $9.73 \pm 0.5 \mathrm{I}^{\mathrm{a}, \mathrm{d}, \mathrm{e}, \mathrm{h}}$ & 50.86 & $11.33 \pm 2.16^{\mathrm{e}, \mathrm{h}}$ \\
\hline $\mathrm{CF} 400 \mathrm{mg} / \mathrm{kg}$ & $5.73 \pm 0.34^{\mathrm{a}, \mathrm{d}, \mathrm{c}, \mathrm{e}, \mathrm{h}}$ & 71.06 & $17.50 \pm 2.19^{\mathrm{d}, \mathrm{e}, \mathrm{g}}$ \\
\hline $\mathrm{CQ} 25 \mathrm{mg} / \mathrm{kg}$ & $0.20 \pm 0.20^{\mathrm{a}, \mathrm{b}, \mathrm{c}, \mathrm{d}, \mathrm{h}}$ & 98.99 & $29.00 \pm 0.63^{\mathrm{a}, \mathrm{b}, \mathrm{c}, \mathrm{h}, \mathrm{d}, \mathrm{g}}$ \\
\hline
\end{tabular}

Notes: Data are expressed as mean \pm SEM; $[\mathrm{n}=6]$. ${ }^{\mathrm{a} C}$ Compared to negative control; ${ }^{\mathrm{b}}$ Compared to $100 \mathrm{mg} / \mathrm{kg}$; ${ }^{\mathrm{c}} \mathrm{Compared}$ to $200 \mathrm{mg} / \mathrm{kg}$; ${ }^{\mathrm{d}} \mathrm{Compared}$ to $400 \mathrm{mg} / \mathrm{kg}$; ${ }^{\mathrm{e}}$ Compared to CQ 25mg/kg: ${ }^{\mathrm{f}} \mathrm{p}<0.05,{ }^{\mathrm{g}} \mathrm{p}<0.0 \mathrm{I},{ }^{\mathrm{h}} \mathrm{p}<0.00 \mathrm{I}$.

Abbreviations: $\mathrm{CQ}$, chloroquine; $\mathrm{CON}$, control; $\mathrm{CM}$, crude methanolic extract of Combretum molle. 


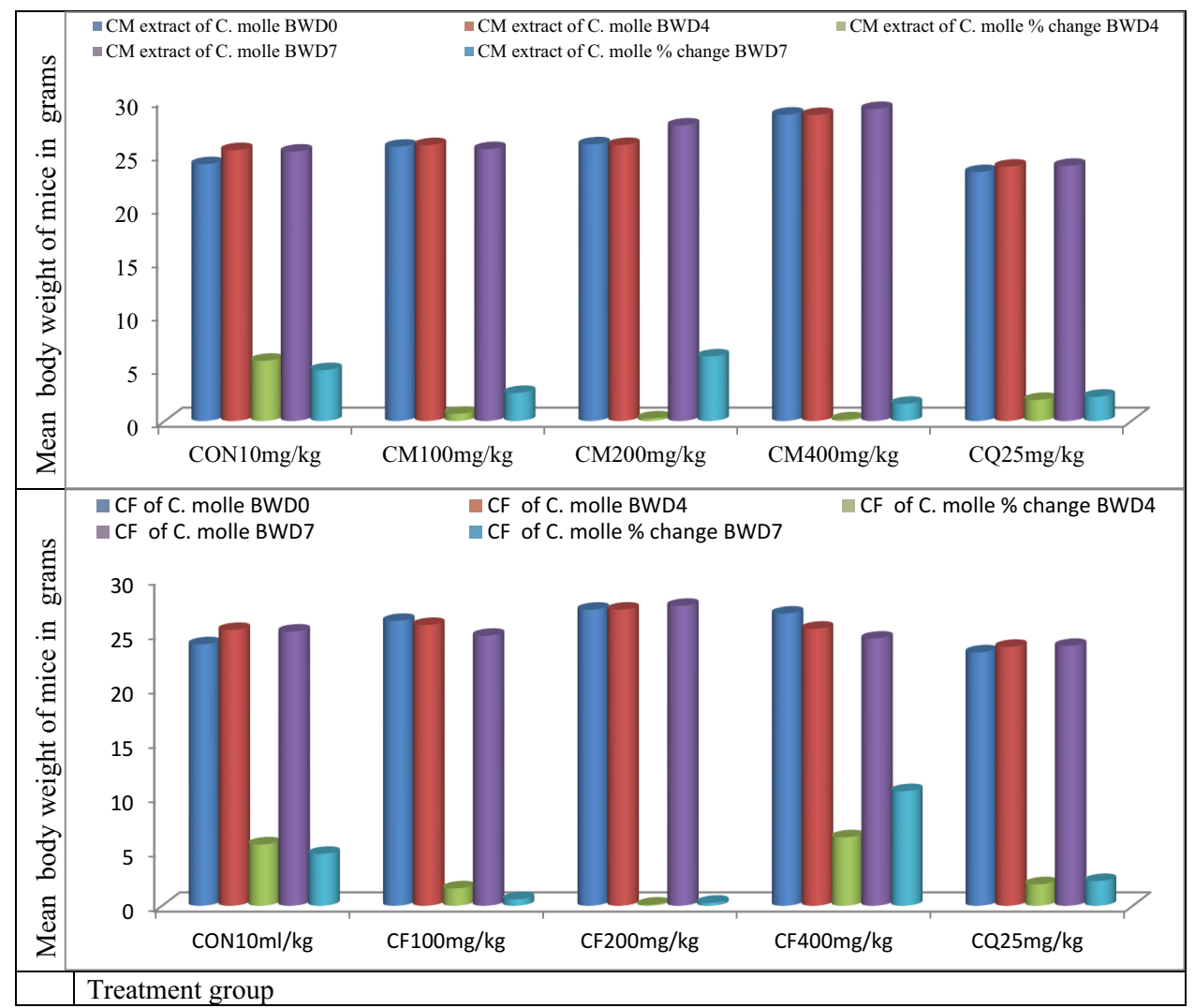

Figure 6 Effect of crude methanolic extract and chloroform fraction of $C$. molle on body weight of $P$. berghei infected mice in a prophylactic test. [N $=6$ ]. Abbreviations: BTD0, body temperature at day zero; BTD7, body temperature at day seven; CON, negative control; CM, crude methanolic extract; CF, chloroform fraction; $\mathrm{CQ}$, chloroquine.

activities of the leaf of $C$. molle methanol $(80 \%)$ crude extract and solvent fractions were evaluated. The methanolic crude extract yield of C. molle leaves was 19.13\% while not determined in studies done on root bark and stem bark. ${ }^{22,23}$ This high yield of methanolic extract might be because of the high efficiency of $80 \%$ methanol in partitioning a wider polarity range of compounds than pure methanol.

The medicinal plant (C. molle) contains considerable constituents of secondary bioactive constituents like alkaloids, flavonoids, phenols, saponins, sterols, tannins, and terpenoids. The antimalarial effects of both methanolic crude extract and chloroform fraction of $C$. molle leaves have higher mean percent parasitemia inhibition, reduction in weight and temperature than hexane and aqueous fractions. Alkaloids are attributed to their ability to intercalate with DNA and terminate division of cells. ${ }^{27}$ Flavonoids' ability to complex with extracellular and soluble proteins and to complex with organisms' cell components. More lipophilic flavonoids may disrupt microbial membranes, inactivate toxins, and inhibited isolated enzymes and complexing activities. ${ }^{29,30}$ Phenolic toxicity produced by phenolic compounds to microorganisms includes enzyme inhibition by the oxidized compounds, possibly through reaction with sulfhydryl groups or through more nonspecific interactions with the proteins. ${ }^{31}$ Tannins stimulate phagocytic cells, host-mediated tumor activity complexation with proteins through so-called nonspecific forces like hydrogen bonding and hydrophobic effects, further as by chemical bond formation. ${ }^{41}$ The terpenes' mechanism of action is not fully understood but is alleged to involve membrane disruption by the lipophilic compounds. ${ }^{29,30}$ Methanolic leaf extract failed to cause any overt morbidity and mortality in the experimental mice at $2000 \mathrm{mg} / \mathrm{kg}$ oral administration. This showed that a median lethal dose of $50 \%\left(\mathrm{LD}_{50}\right)$ is larger than $2000 \mathrm{mg} / \mathrm{kg}$, which attests that plant products are frequently considered to be safe and have fewer adverse effects than synthetic ones. ${ }^{37,38}$ However, species variations would limit such a clear-cut extrapolation of the findings of this study to humans. On subacute toxicity study of mice, there was a discount in mean weight of liver and kidneys. This might occur to those organs are majorly involved in both 


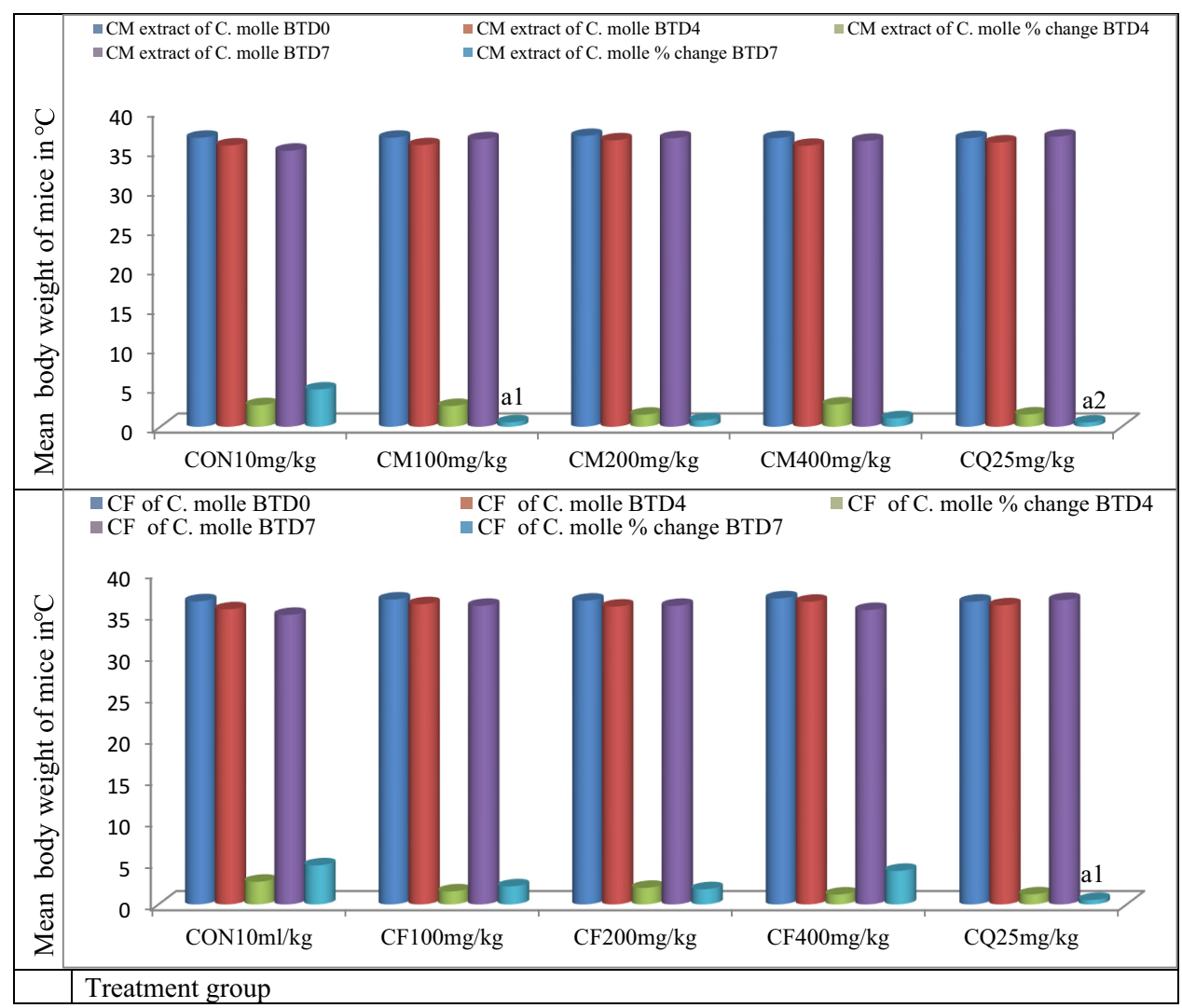

Figure 7 Effect of crude methanolic extract and chloroform fraction of $C$. molle on body temperature of $P$. berghei infected mice in a prophylactic test. [N $=6$ ]. Compared to negative control: ${ }^{\mathrm{a} 1} \mathrm{p}<0.05,{ }^{\mathrm{a} 2} \mathrm{p}<0.01$.

Abbreviations: BTD0, body temperature at day zero; BTD7, body temperature at day seven; CON, negative control; CM, crude methanolic extract; CF, chloroform fraction; $\mathrm{CQ}$, chloroquine.

metabolism and excretion with this work load their mass is also decreased because the dose of the extract is increased to $400 \mathrm{mg} / \mathrm{kg}$. The in vivo antiplasmodial activities of C. molle crude extract and solvent fractions were investigated by evaluating the chemo-suppression during early infection, while crude extract and chloroform fraction were wont to evaluate the curative and prophylactic activity of the plant during established infection. In suppressive, curative, and prophylactic tests, determination of percent parasitemia inhibition and improved survival days are widely used parameters for evaluating antiplasmodial activity. ${ }^{44,45}$ The methanolic crude extract and chloroform fraction at 100 , 200 , and $400 \mathrm{mg} / \mathrm{kg}$ showed significant percent parasitemia inhibition than the hexane and aqueous fractions, they were further evaluated in curative and prophylactic test. ${ }^{44,45}$ In the 4-day chemosuppressive, curative and prophylactic test methanolic crude extract and solvent fractions of $C$. molle leaves produced dose-dependent mean percent parasitemia inhibition and prolonged the survival days of $P$. berghei infected mice, the results recorded at the doses administered.
Parasitemia level $P$. berghei infected treated with methanolic crude extract and solvent fractions of $C$. molle leaves was but mice treated with solvent due to a suppressive effect on the multiplication and erythrocyte infectivity of $P$. berghei parasites in mice. Chloroform fraction demonstrated dose-dependent higher activity in blood parasitemia inhibition against $P$. berghei than other fractions. The relatively higher activity of the chloroform fraction may well be due to secondary metabolites which could be partitioned during fractionation. ${ }^{27-30}$ The mean survival time could be a vital parameter to evaluate the antimalarial activity of plant extracts. ${ }^{44}$ The methanolic crude extract and solvent fractions of $C$. molle leaves prolonged the survival time of $P$. berghei infected mice dose dependently. This may well be because of the presence of secondary metabolites that prevent the pathologic effect of the parasite within the infected mice. ${ }^{27-31}$

Comparing the mean survival time of chloroform fraction and methanolic crude extract, mice treated with chloroform fraction showed lower mean survival time; this might be because of the feed intake depressing effect 


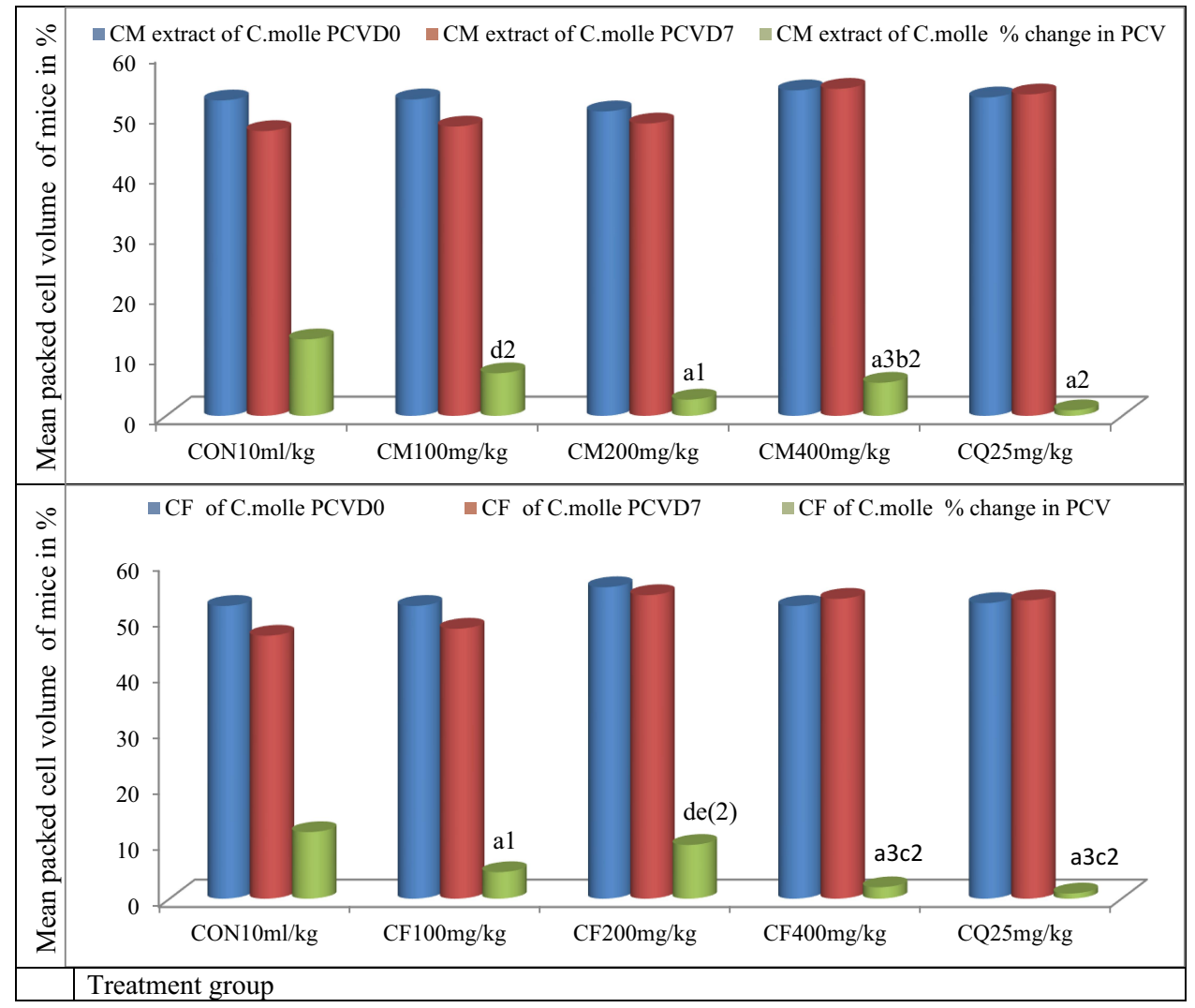

Figure 8 Effect of crude methanolic extract and chloroform fraction of $C$. molle on packed cell volume of $P$. berghei infected mice in a prophylactic test. [N $=6$ ]. Compared to negative control: ${ }^{\mathrm{a}} \mathrm{p}<0.05,{ }^{\mathrm{a} 2} \mathrm{p}<0.0 \mathrm{I}$, ${ }^{\mathrm{a} 3} \mathrm{p}<0.00 \mathrm{I}$, compared to $100 \mathrm{mg} / \mathrm{kg}$ : ${ }^{\mathrm{b} 2} \mathrm{p}<0.0 \mathrm{I}$, compared to $200 \mathrm{mk} / \mathrm{kg}$ : ${ }^{\mathrm{c} 2} \mathrm{p}<0.0 \mathrm{l}$, compared to $400 \mathrm{mg} / \mathrm{kg}$ : ${ }^{\mathrm{d} 2} \mathrm{p}<0.0 \mathrm{I}$, compared to $\mathrm{CQ} 10 \mathrm{mg} / \mathrm{kg}:{ }^{\mathrm{e} 2} \mathrm{p}<0.01$.

Abbreviations: PCV0, packed cell volume at day zero; PCV7, packed cell volume at day zero; CON, negative control (solvent $10 \mathrm{~mL} / \mathrm{kg}$ ); CM, Crude hydromethanolic extract; CF, chloroform fraction of CM; CQ, chloroquine.

of metabolites and interfere with the protein digestion by secondary metabolites. ${ }^{40}$ In comparing the result obtained from this study, the three doses of crude methanolic extract and chloroform fraction of C. molle leaves showed significant mean percent parasitemia inhibition compared to the negative control. In vivo antiplasmodial activity is additionally classified as moderate, good, and very good if extract displayed percent parasite inhibition is $\geq 50 \%$ at a dose of 500,250 , and $100 \mathrm{mg} / \mathrm{kg}$ weight per day, respectively. ${ }^{13}$ Supported this classification, the methanolic crude extract of C. molle leaves at $400 \mathrm{mg} /$ $\mathrm{kg}$ /day showed $76.17 \%$, and chloroform fraction at 400 , 200 , and $100 \mathrm{mg} / \mathrm{kg} /$ day showed $67.73 \%, 54.32 \%$, and $52.93 \%$ parasitemia inhibition against $P$. berghei infected mice, respectively, and exhibited moderate, good, and very good antiplasmodial activity. A stronger percentage of parasitemia inhibition was observed in chloroform fraction than the crude methanolic extract at 100 and $200 \mathrm{mg} / \mathrm{kg}$ doses but under at $400 \mathrm{mg} / \mathrm{kg}$ dose. These results indicated that compounds which have antimalarial activity were soluble in the solvent accustomed extract and fractionate the leaves of $C$. molle for antimalarial activity. Weight and body temperature are the distinctive features of plasmodium infection in mice, indicating that a good antimalarial agent should prevent temperature and weight reduction in Plasmodium infected mice. The dosedependent suppressive activities of the leaves of C. molle crude extract and solvent fractions propose that crude extract and solvent fractions do not have any toxic effects in experimental mice at the doses evaluated. In the curative test, the common percent parasitemia was increased in the negative control from the 3 rd day to the 7 th day. The Plasmodium berghei infected mice treated with methanolic crude extract and chloroform fraction of $C$. molle leaves the mean percent parasitemia increased from the day -3 to day -4 and showed a decrease in percent parasitemia from the day -5 to day -7 in a dose-dependent manner compared to the negative control. The infected mice treated with Chloroquine base showed a decrease in average percent parasitemia from $3^{\text {rd }}$ day to the $7^{\text {th }}$ day. 
In the curative test methanolic crude extract and chloroform fraction of $C$. molle leaves produced significant difference in percent packed cell volume compared to the negative control. The methanolic crude extract and chloroform fraction of $C$. molle leaves at doses of 100,200 , and $400 \mathrm{mg} / \mathrm{kg} /$ day showed increased mean survival time compared to the negative control but only produced significant difference at $400 \mathrm{mg} / \mathrm{kg} /$ day compared to negative control. Methanolic crude extract and chloroform fraction of $C$. molle leaves in prophylactic test at 100,200 , and $400 \mathrm{mg} / \mathrm{kg} /$ day and Chloroquine base at $25 \mathrm{mg} / \mathrm{kg} /$ day showed highly significant $(\mathrm{P}<0.001)$ difference compared to the negative control group at day-7.

\section{Conclusion}

Methanolic crude extract and solvent fractions of $C$. molle leaves have in vivo anti-malarial activities. The lack of acute and subacute toxicity and antimalarial activity upholds the earlier in vitro findings as well as the folkloric use in Ethiopian traditional medicine.

\section{Recommendation}

We forward the recommendation for investigators to carry out in-depth study to isolate, identify, and characterize the bioactive constituents responsible for antimalarial activity of leaf of the C. molle. In the present study acute and subacute toxicity was done showing that the plant was safe. Therefore, we recommend performing chronic histopathological and biochemical toxicity study of the plant.

\section{Data Sharing Statement}

The datasets used and/or analysed during the current study are available from the corresponding author on reasonable request.

\section{Ethical Approval}

The ethical clearance was requested and obtained from the Department of Pharmacology/University of Gondar Ethics and Research Committee, Gondar-Ethiopia (SOP4/96/ 2011). And the research was performed as per the agreement of internationally accepted documents ${ }^{36,37}$.

\section{Acknowledgment}

We are very grateful to University of Gondar for the approval of the ethical clearance, laboratory facility, and authentication of the plant material and for their technical supports. Lastly, we would like to thank the Ethiopian public health institute for the free delivery of $P$. berghei parasite.

\section{Author Contributions}

All authors made substantial contributions to conception and design, acquisition of data, or analysis and interpretation of data; took part in drafting the article or revising it critically for important intellectual content; agreed to submit to the current journal; gave final approval of the version to be published; and agree to be accountable for all aspects of the work.

\section{Funding}

No source of funding.

\section{Disclosure}

The authors declare that they have no conflicts of interest for this work to disclose.

\section{References}

1. Buffet PA, Safeukui I, Deplaine G, et al. The pathogenesis of Plasmodium falciparum malaria in humans: insights from splenic physiology. Blood. J Am Soc Hematol. 2011;117(2):381-392.

2. Cowman AF, Crabb BS. Invasion of red blood cells by malaria parasites. Cell. 2006;124(4):755-766. doi:10.1016/j.cell.2006.02.006

3. Lee RS, Waters AP, Brewer JM. A cryptic cycle in haematopoietic niches promotes initiation of malaria transmission and evasion of chemotherapy. Nat Commun. 2018;9(1):1-9. doi:10.1038/s41467017-02088-w

4. Cohuet A, Harris C, Robert V, Fontenille D. Evolutionary forces on anopheles: what makes a malaria vector? Trends Parasitol. 2010;26 (3):130-136. doi:10.1016/j.pt.2009.12.001

5. Reyburn H. New WHO guidelines for the treatment of malaria. $B M J$ (Clinical Research Ed). 2010;340(may28 1):c2637. doi:10.1136/bmj. c2637

6. Zhang Y, Xie L, Xie L, Bourne P. The Plasmodium falciparum drugome and its polypharmacological implications. bioRxiv. 2016;042481.

7. White NJ. Counter perspective: artemisinin resistance: facts, fears, and fables. Am J Trop Med Hyg. 2012;87(5):785. doi:10.4269/ ajtmh.2012.12-0573

8. WHO. World malaria report 2018. ISBN 978-92-4-156565-3

9. Guerra CA, Snow RW, Hay SI. Mapping the global extent of malaria in 2005. Trends Parasitol. 2006;22(8):353-358. doi:10.1016/j. pt.2006.06.006

10. Lai S, Sun J, Ruktanonchai NW, et al. Changing epidemiology and challenges of malaria in China towards elimination. Malar J. 2019;18 (1):107. doi:10.1186/s12936-019-2736-8

11. Rogerson SJ, Mwapasa V, Meshnick SR. Malaria in pregnancy: linking immunity and pathogenesis to prevention. In Defining and defeating the intolerable burden of Malaria III: progress and perspectives: supplement to volume 77 (6) of American Journal of Tropical Medicine and Hygiene. Am J Trop Med Hyg. 2007.

12. Woime AW Changes in the Spread of Malaria in Ethiopia: Case Study from Awassa and Hossana Area 2006-2007 [Master's thesis]. Høgskolen i Telemark.

13. Deressa W, Olana D, Chibsa S. Magnitude of malaria admissions and deaths at hospitals and health centers in Oromia, Ethiopia. Ethiop Med J. 2004;42(4):237-246. 
14. Eyasu M, Shibeshi W, Giday M. In vivo antimalarial activity of hydromethanolic leaf extract of Calpurnia aurea (Fabaceae) in mice infected with chloroquine sensitive Plasmodium berghei. Int $J$ Pharmacol. 2013;2:131-142.

15. Lima GR, de Sales IR, Caldas Filho MR, et al. Bioactivities of the genus combretum (combretaceae): a review. Molecules. 2012;17(8).

16. Keay RW. Trees of Nigeria. Clarendon Press; 1989.

17. Mesfin F, Seta T, Assefa A. An ethnobotanical study of medicinal plants in Amaro Woreda, Ethiopia. Ethnobot Res Appl. 2014;12:341354. doi:10.17348/era.12.0.341-354

18. Meragiaw M, Asfaw Z, Argaw M. The status of ethnobotanical knowledge of medicinal plants and the impacts of resettlement in Delanta, northwestern Wello, northern Ethiopia. Evid Based Complement Alternat Med. 2016;2016:1-24. doi:10.1155/2016/5060247

19. Asres K, Balcha F. Phytochemical screening and in vitro antimalarial activity of the stem bark of Combretum molle $\mathrm{R}$. Br ex G Don. Ethiopian Pharm J. 1998;16:25-33.

20. Atindehou KK, Schmid C, Brun R, Koné MW, Traore D. Antitrypanosomal and antiplasmodial activity of medicinal plants from Côte d'Ivoire. J Ethnopharmacol. 2004;90(2-3):221-227. doi:10.1016/j.jep.2003.09.032

21. Gansané A, Sanon S, Ouattara LP, et al. Antiplasmodial activity and toxicity of crude extracts from alternatives parts of plants widely used for the treatment of malaria in Burkina Faso: contribution for their preservation. Parasitol Res. 2010;106(2):335. doi:10.1007/s00436009-1663-y

22. Anato M, Ketema T. Anti-plasmodial activities of Combretum molle (Combretaceae) [Zwoo] seed extract in Swiss albino mice. BMC Res Notes. 2018;11(1):312. doi:10.1186/s13104-018-3424-4

23. Mulaw T, Wubetu M, Dessie B, Demeke G, Molla Y. Evaluation of antimalarial activity of the $80 \%$ methanolic stem bark extract of Combretum molle against Plasmodium berghei in Mice. $J$ Evid Based Integr Med. 2019;24:2515690X19890866. doi:10.1177/ 2515690X19890866

24. Asnake S, Teklehaymanot T, Hymete A, Erko B, Giday M. Evaluation of the antiplasmodial properties of selected plants in southern Ethiopia. BMC Complement Altern Med. 2015;15(1):448. doi:10.1186/s12906-015-0976-x

25. Alemayehu MA, Abdelwuhab M, Gelayee DA. In-vivo anti-malarial activity of crude extract and solvent fractions of the roots of Clematis simensis Fresen. (Ranunculaceae) in Plasmodium berghei infected mice.

26. Zohra SF, Meriem B, Samira S, Muneer MA. Phytochemical screening and identification of some compounds from mallow. J Nat Prod Plant Resour. 2012;2(4):512-516.

27. Alafid F, Edrah SM, Meelad FM, Belhaj S, Altwair K, Maizah NR. Evaluation of phytochemical constituents and antibacterial activity of Thymelaea hirsuta (1.) Endl, and that utilised as a conventional treatment of infertility and diabetic in Libya. World $J$ Pharm Res. 2019;8(11):72-88

28. Scalbert A. Antimicrobial properties of tannins. Phytochemistry. 1991;30(12):3875-3883. doi:10.1016/0031-9422(91)83426-L

29. Usman H, Abdulrahman FI, Usman A. Qualitative phytochemical screening and in vitro antimicrobial effects of methanol stem bark extract of Ficus thonningii (Moraceae). Afr J Trad CAM. 2009;6 (3):289-295.

30. Ochieng CO, Midiwo JO, Owuor PO. Anti-plasmodial and larvicidal effects of surface exudates of Gardenia ternifolia aerial parts.

31. Ozcan T, Akpinar-Bayizit A, Yilmaz-Ersan L, Delikanli B. Phenolics in human health. Int J Chem Eng Appl. 2014;5(5):393. doi:10.7763/ IJCEA.2014.V5.416

32. Cowan MM. Plant products as antimicrobial agents. Clin Microbiol Rev. 1999;12(4):564-582.
33. Dibua UM-E, Concilia OC, Chioma U, Kenechukwu FC, Austin O. In vivo antimalarial and cytotoxicity activity of ethanolic stem bark of Petersianthus macrocarpus and leaf of Astonia boonei in experimental mice model. Int J Curr Microbiol App Sci. 2013;2(12):354368.

34. Othman L, Sleiman A, Abdel-Massih RM. Antimicrobial activity of polyphenols and alkaloids in Middle Eastern plants. Front Microbiol. 2019;10:911. doi:10.3389/fmicb.2019.00911

35. Omojate Godstime C, Enwa Felix O, Jewo Augustina O, Eze Christopher O. Mechanisms of antimicrobial actions of phytochemicals against enteric pathogens-a review. J Pharm Chem Biol Sci. 2014;2(2):77-85.

36. Gollapudi S, Sharma HA, Aggarwal S, Byers LD, Ensley HE, Gupta $\mathrm{S}$. Isolation of a previously unidentified polysaccharide (MAR-10) from Hyssop officinalis that exhibits strong activity against human immunodeficiency virus type 1. Biochem Biophys Res Commun. 1995;210(1):145-151. doi:10.1006/bbrc.1995.1639

37. Organization for Economic Co-operation and Development. Test No. 425: Acute Oral Toxicity: Up-And-Down Procedure. OECD Publishing; 2008.

38. Mohr BJ, Fakoya FA, Hau J, Souilem O, Anestidou L. The governance of animal care and use for scientific purposes in Africa and the Middle East. ILAR J. 2016;57(3):333-346. doi:10.1093/ilar/ilw035

39. Parasuraman S. Toxicological screening. J Pharmacol Pharmacother. 2011;2(2):74-79. doi:10.4103/0976-500X.81895

40. Ryley JF, Peters W. The antimalarial activity of some quinolone esters. Ann Trop Med Parasitol. 1970;64(2):209-222. doi:10.1080/ 00034983.1970 .11686683

41. Gurney PC, Elliott SS, Vom E, Spence SJ, Bagnato S, Watkins A, inventors; Leica Biosystems Melbourne Pty Ltd, assignee. Method and apparatus for tissue sample processing. United States patent application US 11/867,760. 2008 May 15.

42. Hegazy R. Hegazy'simplified method of tissue processing (consuming time and chemicals). Ann Int Med Dent Res. 2015;1(2):57.

43. Chong WC, Wu R, Tu AY. A study on tissue processing. Int J Innov Interdiscip Res. 2012;1:37-43.

44. Fidock DA, Rosenthal PJ, Croft SL, Brun R, Nwaka S. Antimalarial drug discovery: efficacy models for compound screening. Supplementary documents. Trends Parasitol. 2004;15:19-29.

45. Bantie L, Assefa S, Teklehaimanot T, Engidawork E. In vivo antimalarial activity of the crude leaf extract and solvent fractions of Croton macrostachyus Hocsht. (Euphorbiaceae) against Plasmodium berghei in mice. BMC Complement Altern Med. 2014;14(1):79. doi:10.1186/1472-6882-14-79

46. Asefa A, Urga K, Guta M, et al. In vivo antimalarial activities of plants used in Ethiopian traditional medicine, Delomenna, Southeast Ethiopia. Ethiop J Health Sci. 2007;17(2):81-89.

47. Iyiola OA, Tijani AY, Lateef KM. Antimalarial activity of ethanolic stem bark extract of Alstonia boonei in mice. Asian J Biol Sci. 2011;4:235-243. doi:10.3923/ajbs.2011.235.243

48. Fentahun S, Makonnen E, Awas T, Giday M. In vivo antimalarial activity of crude extracts and solvent fractions of leaves of Strychnos mitis in Plasmodium berghei infected mice. BMC Complement Altern Med. 2017;17(1):13. doi:10.1186/s12906-016-1529-7

49. Birru EM, Geta M, Gurmu AE. Antiplasmodial activity of Indigofera spicata root extract against Plasmodium berghei infection in mice. Malar J. 2017;16(1):198. doi:10.1186/s12936-017-1853-5

50. Dhanabalan R, Balachandar S, Devakumar J, Sreeraj B, Chandni JN. In vivo antiplasmodial activity of medicinal plants used in pyrexia among ethnic communities of Western Ghats, Coimbatore, Tamil Nadu. J Pharm Res. 2018;12(4):541. 
Journal of Experimental Pharmacology

Dovepress

\section{Publish your work in this journal}

The Journal of Experimental Pharmacology is an international, peerreviewed, open access journal publishing original research, reports, reviews and commentaries on all areas of laboratory and experimental pharmacology. The manuscript management system is completely

online and includes a very quick and fair peer-review system. Visit http://www.dovepress.com/testimonials.php to read real quotes from published authors.

Submit your manuscript here: https://www.dovepress.com/journal-of-experimental-pharmacology-journal 